\title{
Trichodinidae in commercial fish in South America
}

\author{
Patricia Oliveira Maciel • Fabiana Garcia • Edsandra Campos Chagas • \\ Rodrigo Yudi Fujimoto • Marcos Tavares-Dias
}

Received: 30 August 2016/ Accepted: 28 June 2017/Published online: 5 July 2017

(C) Springer International Publishing AG 2017

\begin{abstract}
Ciliates of the family Trichodinidae are protozoan parasites of importance for fish farming in South America, given that at high infestation levels, they cause significant mortality among farmed fish. Although data on economic losses due to parasitosis are not available for South America, mortality outbreaks correlated to trichodinids are very common in the tilapia production chain, especially in Brazil, the largest aquaculture chain in the country. In Brazil in the past, trichodinids were considered only as Trichodina sp. Today, they have been better studied and identified taxonomically in wild and farmed fish. However, in other countries in South America, trichodinids continue to be described only as Trichodina $\mathrm{sp}$. This review presents the history of occurrences of trichodinids in fish of interest in South America, highlighting 15 new species that have been described
\end{abstract}

P. O. Maciel ( $\square)$

Empresa Brasileira de Pesquisa Agropecuária, Embrapa

Pesca e Aquicultura, Postal Box 90, Palmas,

TO 77008-900, Brazil

e-mail: patricia.maciel@embrapa.br

F. Garcia

Agência Paulista de Tecnologia dos Agronegócios/SAA, Postal Box 61, Votuporanga, SP 15500-970, Brazil

e-mail: fgacia@apta.sp.gov.br

E. C. Chagas

Embrapa Amazônia Ocidental, Postal Box 319, Manaus,

AM 69011-970, Brazil

e-mail: edsandra.chagas@embrapa.br in three genera in Brazil, along with information on parasite-host-environment relationships, diagnostic methods and treatments. The occurrence of parasitic ciliates must be correlated with farming conditions such as stress factors, water quality, seasonality, age and host immunity to elucidate the critical points of each production system. Furthermore, for tropical fish, studies on treatment against trichodinid species are needed to provide support for approval of antiparasitic medications for use in fish farming. However, it is recommended that the production sector use intensive production systems that are more sustainable, with biosafety protocols, to increase production and productivity.

Keywords Aquaculture - Fish Disease - Parasites · Protozoan · Trichodina

\author{
R. Y. Fujimoto \\ Embrapa Tabuleiros Costeiros, Avenida Beira Mar, 3250, \\ Bairro Jardins, Aracaju, SE 49025-040, Brazil \\ e-mail: rodrigo.fujimoto@embrapa.br \\ M. Tavares-Dias \\ Embrapa Amapá, Rodovia Juscelino Kubitschek, km 5, \\ 2600, Macapá, AP 68903-419, Brazil \\ e-mail: marcos.tavares@embrapa.br
}




\section{Introduction}

The South American continent is known for its high production and exports in fisheries and aquaculture. Aquaculture plays a particularly important role in food production and in the local economy, in addition to having a large international presence with an impact on the global economy. The production of native fish is currently overtaking the production of non-native species in some countries, which is considered a milestone for South American aquaculture (Valladão et al. 2016b). South America has recorded increases in fish production. In terms of production of freshwater water fish, Brazil is the largest power in the Americas (611.343 tons), and its production in this area is approximately 10 times greater than that of Chile (59.527 tons). The main pathogens of South American fish are similar to those observed throughout the world, such as the bacteria Aeromonas hydrophila, Ichthyophthirius multifiliis, monogeneans and trichodinids (Valladão et al. 2016b).

Organisms of the family Trichodinidae are commonly found in aquatic environments as symbionts. However, they can behave as commensals or parasites of a variety of aquatic vertebrates and invertebrates, such as ciliates, coelenterates planctophagous crustaceans, mollusks, echinoderms, amphibians and fish (Van As and Basson 1987; Basson and Van As 1989; Sabry and Magalhães 2005; Pinto et al. 2006; Dias et al. 2009; Silva-Briano et al. 2011; Martins et al. 2016). Trichodinid species are therefore of great importance for fish farming, given that they parasitize farmed fish. When parasitism levels are high, they can cause epizooty and considerable economic losses in intensive production systems.

Most trichodinids have a conical, rounded or hemispherical body shape (e.g., Tripartiella) that is completely covered with a thin membrane (pellicle) and have a typical structure in the aboral region known as the adhesive disk. The presence of cilia, in both the aboral and adoral regions, provides them with motility in free-living environments and on their hosts and aids in feeding (Basson and Van As 2006). They range in size from 20 to $100 \mu \mathrm{m}$ and can be classified as small, medium or large (Van As and Basson 1987; Basson and Van As 1989; Valladão et al. 2013).

In fish, trichodinids mainly parasitize the skin, fins and gills (Van As and Basson 1987), and less frequently the eyes, mouth, gastrointestinal tract, urinary tract and gonads (Noga 2010; Valladão et al. 2014). In these hosts, they feed on cells, bacteria and detritus from the body surface and are carried by the cilia to the cytostome, which is in the adoral region of the parasite (Basson and Van As 2006; Bruno et al. 2006).

The life cycle of these parasites is monoxenic, and reproduction occurs by means of binary division and, under certain conditions, conjugation (Van As and Basson 1987; Martins et al. 2015). In Trichodina pseudoheterodentata from I. punctatus, during asexual reproduction, the youngest individuals that form immediately are smaller than the older individuals and only possess $50 \%$ as many denticles in their adhesive discs. At subsequent developmental stages, the old ring with $50 \%$ of the usual number of denticles underwent gradual resorption, while a new ring was formed with the usual number of denticles around the old one around the perimeter of the disc (Tang et al. 2017). Wild larvae of amphibians (tadpoles) may be reservoirs of trichodinids for some fish (Lom and Dykova 1992). Trichodinids are present in natural environments but do not occur at high levels of infection in healthy animals (Basson and Van As 2006).

The mechanism of pathogenic action of trichodinids is related to the manner in which they infect their hosts, since when the parasite is fixed firmly onto its host, the border of the aboral membrane creates a suction movement on the surface of the epithelial cells, which likely causes irritation to the tissues of the fish (Basson and Van As 2006). Thus, a high abundance of these parasites and their constant circular movements may seriously damage the epithelium of their hosts, thereby triggering physiological alterations (Van As and Basson 1987).

In the past, trichodinids in Brazil were generally considered only as Trichodina Ehrenberg, 1830 (Martins and Ghiraldelli 2008; Marchiori and Martins 2012), since this is the largest genus of the Trichodinidae, with more than 150 species that parasitize fish (Asmat et al. 2003). In addition to this genus, the family Trichodinidae includes seven of the ten associated genera (Basson and Van As 2006). However, Trichodina Ehrenberg, 1830, Paratrichodina Lom, 1963, Trichodinella (Raabe 1950) Šrámekhušek, 1953, and Tripartiella Lom, 1959, are the genera that have been described as parasitizing aquatic animals in Brazil (Martins et al. 2015). Therefore, it is possible 
that some trichodinids that were previously classified as Trichodina sp. are members of the genera Trichodinella and, especially, Tripartiella (Marchiori and Martins 2012).

The genus Paratrichodina comprises more than eleven species that are known in Europe, Asia, Africa and the United States, of which eight parasitize the gills, and three the urinary tract of fish (Basson and Van As 2006). The few known species of Trichodinella parasitize the gills and are distributed in Europe, Asia, Africa, Middle East, Mexico, United States and Philippines. Tripartiella species have wellknown distribution in Europe, Asia, United States and the Far East (Basson and Van As 2006; Kent and Fournie 2007) but are not well known in South America. In Brazil, only two species of Tripartiella are known (Martins et al. 2015).

In recent years, there has been considerable evolution in taxonomic studies of the diversity of trichodinids among different species of fish in the wild and in farms, especially in Brazil (Fig. 1). The objective of this review was to present a history of the descriptions of occurrence of trichodinids in farmed fish in South America, highlighting new described species and including information about parasite-host relationships, the pathology of infection and methods for diagnosis and treatment.

\section{Trichodinids in farmed fish in Brazil}

In the 1990s, the first studies of the occurrence of trichodinids in teleost fish reared in Brazil appeared, using data from parasitological surveys. In the state of São Paulo, in southeastern Brazil, the first records of the seasonal occurrence of fish mortality associated with parasites and water temperature were obtained between 1983 and 1990 (Ceccarelli et al. 1990). These authors registered mortality rates of $83 \%$ for Colossoma macropomum (tambaqui) and Piaractus mesopotamicus (pacu), 17\% for the hybrids paqui

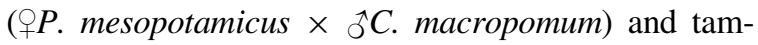
bacu (+C. macropomum $x$ $\widehat{\jmath} P$. mesopotamicus), and $17 \%$ for Ctenopharyngodon idella (grass carp), all associated with infestation by Trichodina sp. Between 1990 and 1991, Figueira and Ceccarelli (1991) identified Trichodina sp. as the most common parasite in fish farms in the northeastern region of the state of São Paulo. In the same region of this state, a survey on

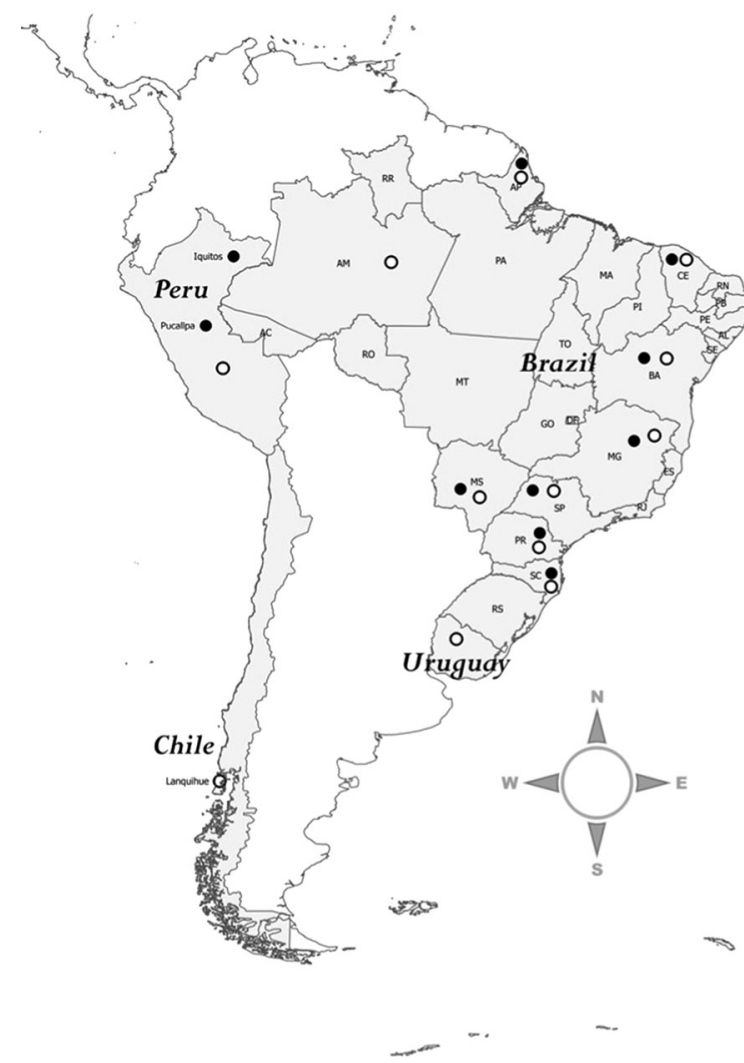

Fig. 1 Distribution of the records of trichodinids in South America (gray countries), with emphasis on Brazil and on new species that have been described over the last ten years. Open circles denote descriptions of Trichodina sp. and solid circles denote the new species that have been described

parasites in fish farms conducted between 1993 and 1998 recorded high mortality among both native and non-native fish, such as pacu, tambaqui, tambacu, Leporinus macrocephalus (piauçu), Brycon cephalus (matrinxã), Oreochromis niloticus (Nile tilapia), Cyprinus carpio (common carp) and Clarias gariepinus (African sharptooth catfish). The stocking density used by the fish farmers ranged from 1 to $8 \mathrm{fish} / \mathrm{m}^{2}$, and the occurrence rate of trichodinids was $9.9 \%$ for these eight fish species evaluated (Martins et al. 2000). Also in the 1990s, the occurrence of Trichodina sp. in tambaquis and common carp in northeastern Brazil was reported (Békési 1992). Additionally, the parasite fauna of fish in two catch-and-pay ponds in the northeastern region of the state of São Paulo, Brazil were reported between April 1997 and March 1999 (Tavares-Dias et al. 2001). They examined B. amazonicus, L. macrocephalus, $P$. mesopotamicus, tambacus, C. carpio, O. niloticus and Tilapia rendalli and found infection due to Trichodina 
sp. in P. mesopotamicus, L. macrocephalus, tambacus and $O$. niloticus. The highest prevalence of infection was in the first two species. In the 1990s, the southern and southeastern regions of Brazil experienced significant development of fish farming, and catch-and-pay enterprises became a common (Tavares-Dias et al. 2001).

Beginning in the 2000s the first studies were published on parasites in native species farmed in the northern and central-western regions of Brazil, along with the first records of species of trichodinids (Table 1). A low prevalence $(0.8 \%)$ of trichodinids was reported in tambatingas $(+C$. macropomum $\times$ ${ }^{1}$ Piaractus brachypomus) in ten fish farms in the state of Amapá, in the Amazon region (Dias et al. 2015); in larvae, post-larvae and fry of cachapinta $(\& P$. reticu-

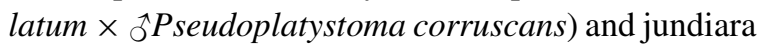
( + Leiarius marmoratus $\times \hat{P}$. reticulatum) in fish farms in the state of Mato Grosso do Sul (Pádua et al. 2012a; Ventura et al. 2013); in P. mesopotamicus and patingas $(\& P$. mesopotamicus $\times \hat{\jmath} P$. brachypomus $)$ in three fish farms in the northwestern region of the state of São Paulo (Franceschini et al. 2013); and in fish in catch-and-pay enterprises in Guariba, state of São Paulo (Schalch and Moraes 2005). A new species of Tripartiella, Tripartiella pseudoplatystomae, was described on the gills and skin of P. corruscans, farmed in Mato Grosso do Sul (Pinto et al. 2009); in addition, occurrences of Trichodina colisae in $P$. mesopotamicus and the hybrid patinga farmed in the central and southeastern regions of Brazil were recorded (Jerônimo et al. 2012). Trichodina heterodentata was recorded in $P$. mesopotamicus (Pádua et al. 2012b) and in Prochilodus lineatus (curimatãs) (Valladão et al. 2013) (Table 1).

In semi-intensive farming, the prevalence of Trichodina sp. on skin and gills of Arapaima gigas (pirarucu) was 69 and 39\%, respectively, and these infestations were accompanied by Dawestrema sp. (Araújo et al. 2009b). Although the species of trichodinid was not described in these last two studies, T. fariai and T. heterodentata have been recorded in pirarucu farmed in Peru (Delgado et al. 2007; Miranda et al. 2012). In the report of T. fariai by Delgado et al. (2007), the morphological characteristics of the parasite were not demonstrated to confirm the description of the species.

For farmed Nile tilapias, studies show that the prevalence of these trichodinids is greater in fish kept in net-cages than in fish kept in excavated ponds. Tilapia, mainly $O$. niloticus, are currently responsible for approximately $60 \%$ of fish-farming production in Brazil (IBGE 2014; Valladão et al. 2016b). This level is due to consolidation of technologies and intensification of production, particularly in net-cages installed in reservoirs of hydroelectric power plants (Pádua and Cruz 2014). Tilapia farming in this system is currently characterized by the use of high stocking densities for the grow-out phase, ranging from 80 to $150 \mathrm{~kg} / \mathrm{m}^{3}$ (600 to more than $900 \mathrm{fish} / \mathrm{m}^{2}$, depending on the phase of cultivation) (Garcia et al. 2013).

In tilapia farmed in ponds in the state of Santa Catarina, southern Brazil, the infection rates due to Trichodina sp. were low, with a prevalence of 5.5 to 22.5\% (Azevedo et al. 2006; Ghiraldelli et al. 2006; Martins and Ghiraldelli 2008), due to mild temperatures. Similarly, for fish in the state of São Paulo, there was low prevalence, ranging from 2.7 to $4.0 \%$ (Tavares-Dias et al. 2001). For fertile Nile tilapia of Thai origin farmed in Maringá, state of Paraná, the prevalence was $17 \%$ (Vargas et al. 2000). A low prevalence of trichodinids was also reported in tilapia farmed with feed consisting of pig waste $(1.7 \%)$ or commercial feed (0.6\%) (Martins et al. 2010a). In farmed tilapia in the Brazilian Amazon region, the prevalence of Trichodina sp. ranged from 3.0 to $4.0 \%$ and for Paratrichodina africana, 7.9\% (Pantoja et al. 2012). However, tilapia farmed in ponds showed prevalences from 10 to $95 \%$ (Jerônimo et al. 2011) (Table 1).

According to historical data, the increased biomass of tilapia stocked in net-cages seems to have contributed to increased proliferation and transmission of trichodinids. At the end of the 1990s, an analysis of ectoparasites on $O$. niloticus kept in net-cages at a density of $10 \mathrm{fish} / \mathrm{m}^{3}$ in the Guarapiranga reservoir, state of São Paulo, showed a low prevalence of Trichodina sp. of $22.3 \%$ on the skin and $6.5 \%$ on the gills (Ranzani-Paiva et al. 2005). However, in a survey conducted more recently on tilapia farmed in netcages at higher densities $\left(133 \mathrm{fish} / \mathrm{m}^{3}\right)$, in the middle stretch of the Paranapanema River on the boundary between the states of São Paulo and Paraná, the prevalence of trichodinids on the skin of fish ranged from 0 to $100 \%$, and findings were more frequent during the winter months (Ayroza et al. 2014). Corroborating these results, Zago et al. (2014) reported higher rates of parasitism due to $T$. compacta 


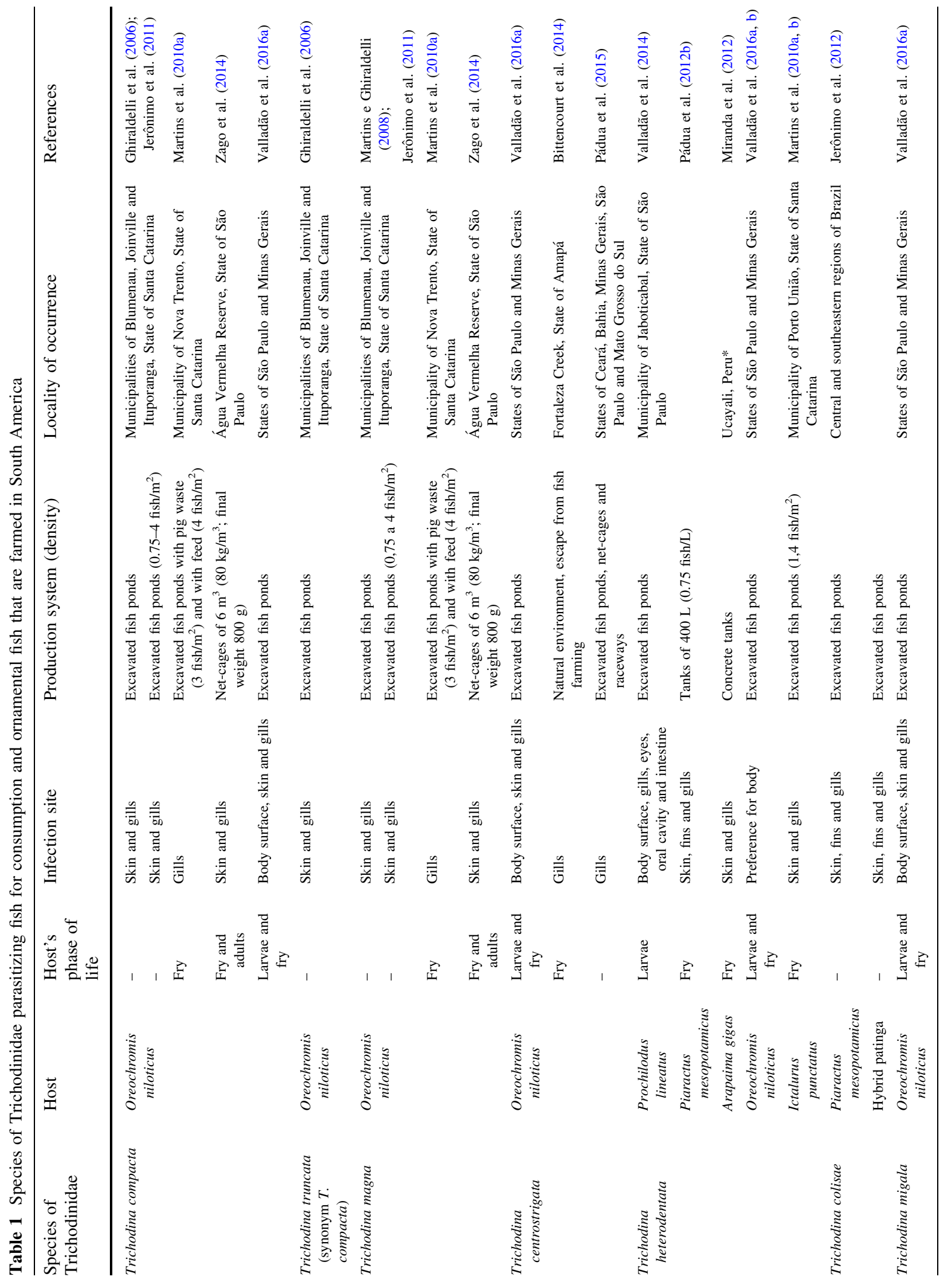




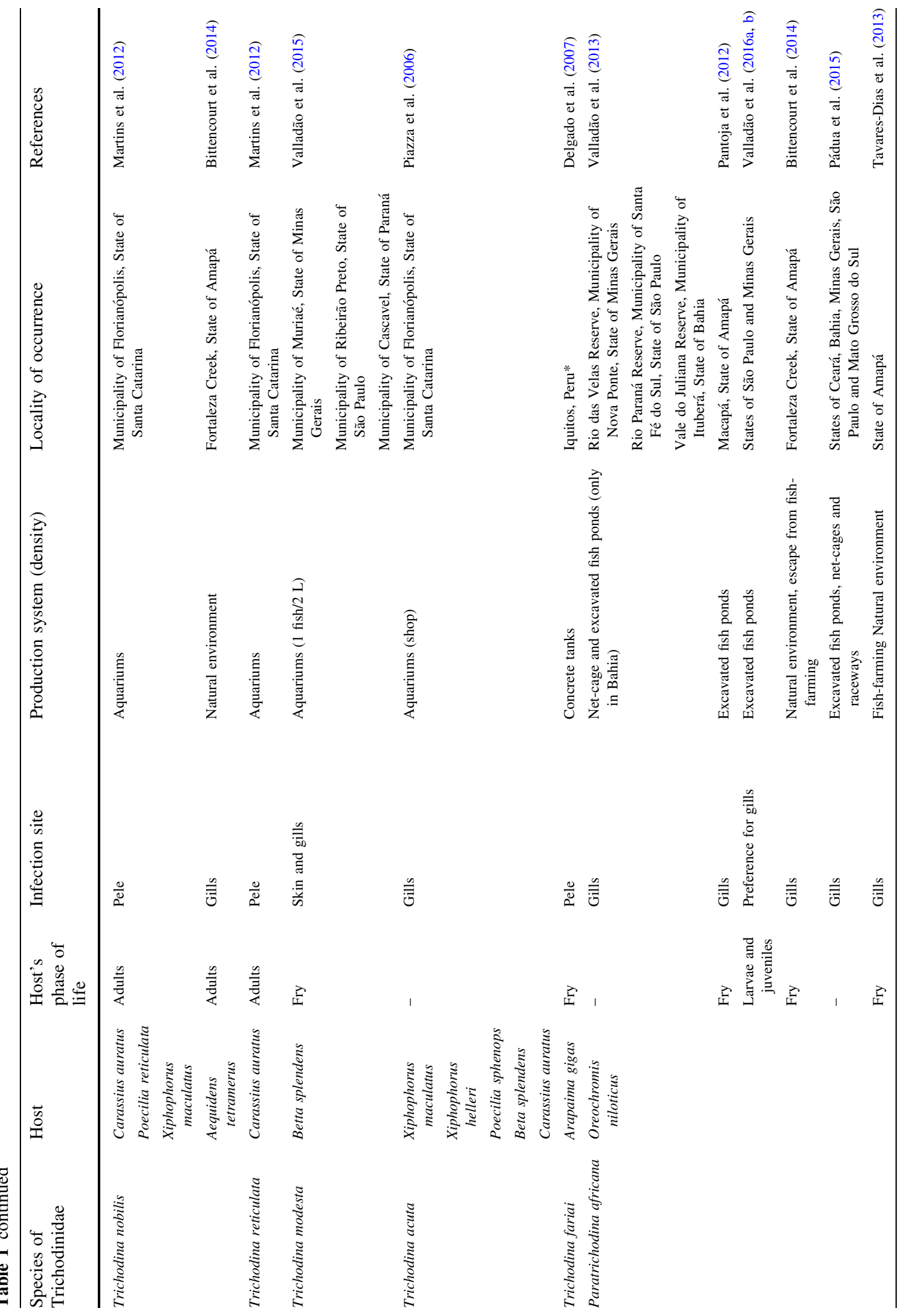


and T. magna (prevalence of $76.2 \%$ to $100 \%$; mean intensity of $23.9 \pm 7.1$ to $603 \pm 405.3$ and mean abundance of $18.2 \pm 5.8$ to $545.5 \pm 367.9$, respectively) among tilapia reared in net-cages in a reservoir in the state of São Paulo. Furthermore, these trichodinids presented the highest frequencies (dominance) among all parasites found (Ichthyophthirius multifiliis, Piscinoodinium pillulare, Epistylis sp. and monogeneans).

In tilapia farmed in net-cages in reservoirs in northeastern Brazil (Bahia) and southeastern Brazil (São Paulo and Minas), the prevalence of P. africana on the gills was $65.9,87.5$ and $100 \%$, respectively, considering both sick and healthy fish (Valladão et al. 2013). Garcia et al. (2013) correlated mortality events among tilapias reared in tanks with different stocking densities, with a high prevalence (66-100\%) of Trichodina sp. on the skin and gills. However, the highest rates of Trichodina sp. were recorded at the highest densities, from which Streptococcus agalactiae (33.3 and 66.7\%) was also isolated. Associations between trichodinids and secondary bacteriosis are known (Basson and Van As 2006), not only due to losses in Brazilian tilapia farming due to parasitic and bacterial diseases (Pádua and Cruz 2014) but also because the response to vaccination against $S$. agalactiae is reduced in fish that are parasitized by $T$. heterodentata, Gyrodactylus cichlidarum and I. multifiliis (Martins et al. 2011). Thus, these authors highlighted the importance of monitoring and controlling parasitism levels before conducting vaccination programs among farmed fish. However, at the reproduction and fry phases of farming of $O$. niloticus in net-cages, sanitary conditions influence the grow-out phase (Pádua and Cruz 2014), since Valladão et al. (2016a) reported that in farms in the southeastern region of Brazil, these fish presented three genera of trichodinids and histories of parasitosis and mortality among larvae and fry (Table 1). Thus, production of $O$. niloticus is a major challenge for Brazilian fish farmers, since the production process for $O$. niloticus should start with production of good-quality larvae and fry, with production protocols of greater efficiency, to attain the main objective, which is to produce fish under hygienic, healthy conditions that are acceptable to consumers. However, success in these production methods depends on the technologies available and accepted by the producers. 
In the rearing of ornamental fish, trichodinids have been recorded both in fish for sale in aquarium shops and in fish in the wild or in the stocks of traders who catch and maintain wild fish for sale. A low prevalence of Trichodina sp. was recorded in Xiphophorus helleri (green swordtail) and Xiphophorus maculatus (platy) that were farmed both in tanks (13\%) and in excavated ponds (54\%) in the state of São Paulo (Garcia et al. 2009). Recently, Santos et al. (2017) reported low prevalence rates of T. heterodentata (23\%) Xiphophorus maculatus as well as Trichodina sp. (10\%) in Xiphophorus helleri of three facilities of ornamental fish from the state of Santa Catarina. Trichodina acuta was found at a low prevalence $(4.7 \%)$ and medium intensity (1-31) in five species of ornamental fish in shops (Piazza et al. 2006), while T. nobilis and $T$. reticulata $\mathrm{sp}$. infected half of the 95 fish analyzed in a shop in Florianópolis, Santa Catarina (Martins et al. 2012) (Table 1). By evaluating fish caught in a creek that forms a tributary of the Negro River in the state of Amazonas, Tavares-Dias et al. (2010) found Trichodina spp. only in the gills of Carnegiella strigata (14.3\%), Carnegiella marthae (7.9\%) and Nannostomus eques $(9.7 \%)$, with the highest mean intensity in C. strigata $(6.5 \pm 3.5$ parasites/fish). Trichodina modesta, which was described only in Eurasia and as a specific parasite of Cypriniformes, was also found by Valladão et al. (2015) for the first time, infecting $B$. splendens in Brazil. This is therefore the first report of this trichodinid in the Americas (Table 1).

The ornamental fish market has grown over the last ten years. Among the fish placed on the market, $90 \%$ were produced through farming, and only $10 \%$ were caught in the wild, mostly in the Amazon region for export (Tavares-Dias et al. 2009). Trichodinid species have a worldwide distribution that has increased because of transcontinental shipments of ornamental fish (Basson and Van As 2006). Introduction of cichlids from Africa to countries such as Brazil has resulted in the introduction of trichodinids into this country. Trichodina nobilis can access the host Aequidens tetramerus, which is an ornamental fish native to the Amazon region, possibly transmitted by specimens of $O$. niloticus that escaped from fish farms in the region of Macapá, state of Amapá (Bittencourt et al. 2014). In this region, A. tetramerus was also found to be parasitized by Tripartiella tetramerii (Fig. 2), which was the first trichodinid described in the Amazon region (Martins et al. 2016). It was observed that $A$. tetramerus acquired only this species of trichodinid, among the diversity of parasites found in its cohabitant $O$. niloticus, possibly because of difficulty in accessing a community of ectoparasites that already existed in native species. Paratrichodina africana is another exotic parasite that has been introduced into Brazil, likely through importation of
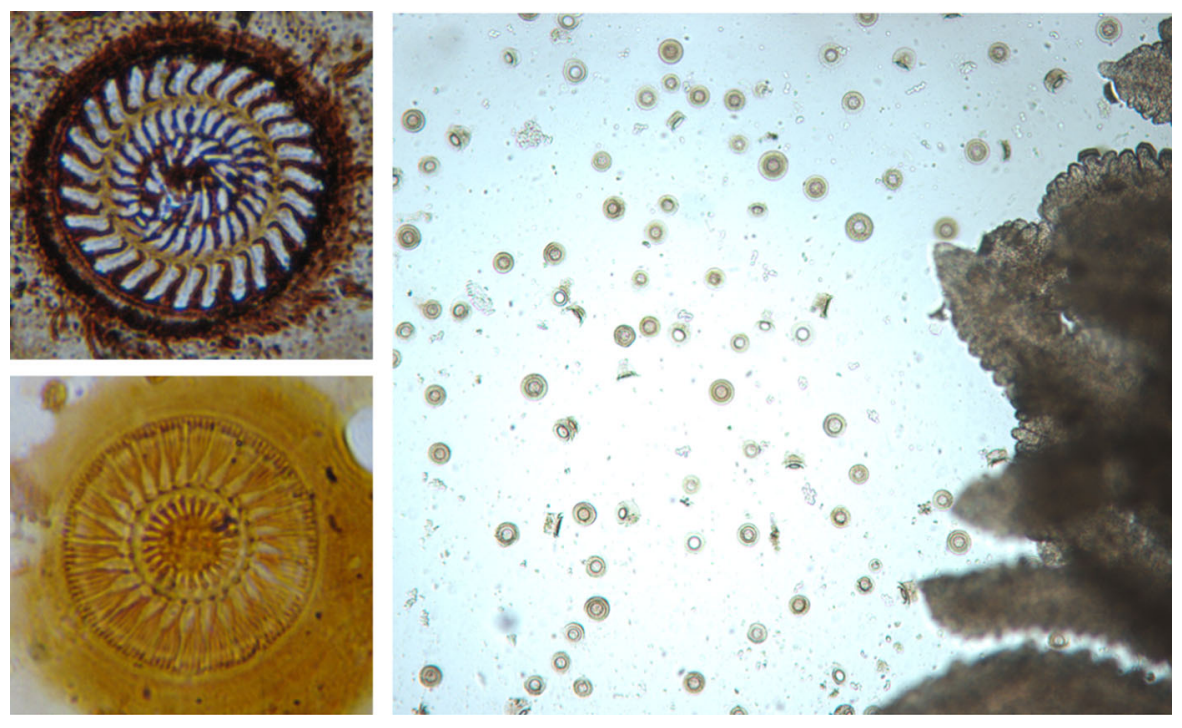

Fig. 2 Trichodina sp. in gills of pirarucu fingerlings (larger image); Trichodina centrostrigata ectoparasite of Nile tilapias (above) and Tripartiella tetramerii described in a Brazilian cichlid (below) 
O. niloticus for aquaculture (Valladão et al. 2013). Because of these results and evaluation of recent studies on taxonomic identification of trichodinids, it can be supposed that transport of other species of trichodinids to Brazil may have also occurred.

\section{Trichodinids in fish farmed in Peru, Argentina, Chile, Colombia, Venezuela and Uruguay}

In South America, parasites such as Trichodina sp. (Rojas and Wadsworth 2007) are major health problems in net-cage fish farming, especially in tilapias; this is because during the reproductive period, parasites invade the mouths of fertile fish and transmit the infection to the larvae (Conroy 2001).

In Peru, infection due to Trichodina sp. has been reported to cause problems in rearing the fry of Oreochromis spp. (Gonzales-Fernández 2012), Osteoglossum bicirrhosum (Vázquez et al. 2007), Piaractus brachypomus (Alcántara-Bocanegra et al. 2015), and Arapaima gigas (Delgado et al. 2013; SerranoMartínez et al. 2015). However, Trichodina fariai (Delgado et al. 2007) and Trichodina heterodentata (Miranda et al. 2012) are the species that are known to parasitize A. gigas (Table 1).

In Argentina, although several native species (Odontesthes bonariensis, Odontesthes hatcheri, Leporinus obtusidens, $P$. mesopotamicus, Rhamdia quelen, $P$. corruscans and $P$. lineatus) and non-native species (Salminus brasiliensis, Salmo salar, Oncorhynchus mykiss, Ctenopharyngodon idella, $C$. carpio, Oreochromis mossambicus and Acipenser baerii) are farmed, there are no studies on infection due to trichodinids. However, such studies have been conducted on populations of wild fish, and the occurrence of Trichodina sp. in R. quelen, Astyanax spp. and $O$. bonariensis has been recorded (Vanotti and Tanzola 2005; Tanzola et al. 2009), while Trichodina puytoraci Lom, 1962, Trichodina lepsii Lom, 1962, and Trichodina scalensis Marcotegui; Martorelli, 2009 have been reported in Mugil platanus and Trichodina murmanica Poljansky, 1955 in $\mathrm{Mi}$ cropogonias furnieri in marine environments (Marcotegui and Martorelli 2009).

In Chile, in freshwater salmonids (Oncorhynchus kisutch, O. tshawytscha and O. mykiss) farmed in netcages, trichodinids have only been described as Trichodina sp. (Wood 1970; Bravo 2007). However,
Trichodina lascrucensis is known and has been described as a parasite of the marine fish Scartichthys viridis (Khan et al. 2008).

In Colombia, only Trichodina sp. has been recorded, parasitizing farmed fish such as $P$. brachypomus (Verján et al. 2001; Carrillo et al. 2007; Pulido and Iregui 2008), C. macropomum (Pulido and Iregui 2008/2009), and its hybrids, Prochilodus magdalenae (Calderon et al. 2003) and Oreochromis spp. (Carrillo et al. 2007). Although C. carpio, Oncorhynchus mykiss, Pseudoplatystoma fasciatum and Brycon moorei (Sanabria 2012) are also farmed in Colombia, infection by trichodinids has not been investigated in these fish.

In Uruguay, infection due to Trichodina sp. has been found to occur in Mugil platanus, O. bonariensis, $R$. quelen, C. carpio, C. idella, Acipenser baerii, Acipenser gueldenstaedtii, O. niloticus (Carnevia et al. 2010), Xiphophorus helleri (Carnevia and Speranza 2003a), Carassius auratus and 19 other species of farmed ornamental fish (Carnevia and Speranza 2003b).

Among fish farmed in Venezuela, infection due to Trichodina sp. has been studied in C. macropomum and its hybrid ( $q$ C. macropomum $\times$ ô P. brachypomus) (Mujica and Armas 1985; Centeno et al. 2004). However, parasitism due to trichodinids has not been investigated in other farmed species, such as $O$. mykiss, hybrids of Oreochromis mossambicus $\times O$. urolepis $\times O$. niloticus $\times O$. aureus, $C$. macropomum, P. brachypomus, Mylossoma duriventre, Phractocephalus hemioliopterus, Astronotus ocellatus, Prochilodus mariae, Cichla orinocensis, P. fasciatum or Leiarius marmoratus. Van As and Basson (1989) reported the occurrence of $T$. heterodentata in $O$. mossambicus in Lake Valência.

In Paraguay, studies of infection due to Trichodina sp. have been conducted only in fish of commercial interest in Lake Yparacaraí (Insaurralde and Romero 2013). No studies on the occurrence of trichodinids in farmed fish in Ecuador, Paraguay, French Guiana or Guyana were found. In all countries cited, the species of trichodinids in farmed fish are still unknown.

\section{Host specificity}

Trichodinids have become specialized for various niches in hosts. Larger species have a broader 
spectrum of preferences among the microenvironments of their hosts, and smaller species generally prefer the gills (Van As and Basson 1987). To formulate these hypotheses, Van As and Basson (1987) studied more than 100 species of fish in 70 localities in South Africa, Taiwan and Israel, from which they classified trichodinids into four groups of species. One group comprised T. acuta and $T$. pedicula, which both have wide geographical distribution, are opportunistic and are located only on the skin and never on the gills. The second group comprised $T$. heterodentata, $T$. minuta, $T$. nigra and T. reticulata, which also had a wide geographic distribution and are predominantly parasites of the skin but also infest the gills of fish. The third comprised T. centrostrigata and T. mutabilis, which predominantly parasitize the gills of fish and occasionally the skin. Trichodina centrostrigata (Fig. 2) was associated with species of cichlids, but when this parasite was present in fish farms, it infected and caused the death of cyprinids that inhabited the same production system (Van As and Basson 1987). Thus, T. centrostrigata was pathogenic to species other than cichlids and presented host specificity in addition to preference for a given micro-habitat. Marchiori and Martins (2012) stated that this host specificity varied according to the environmental quality and fish species present. However, T. mutabilis was found to be a parasite of cyprinids that might occasionally parasitize some species of cichlids if they were farmed together (Van As and Basson 1987). The last of these four groups of trichodinids comprised ten species, of which two were in the genus Trichodinella and eight were in the genus Tripartiella. All species were essentially parasites of the gills and presented a degree of host specificity. The exception was Trichodinella epizootica, which may comprise a pool of species, since it presented a variety of hosts (Van As and Basson 1987). In Brazil, Valladão et al. (2016a) indicated that $T$. heterodentata predominated on the body surface of $O$. niloticus and $P$. africana on the gills of larvae and juveniles of this species, among another four species that were described as cohabiting on this host.

Lastly, the data on relationships between trichodinids and their hosts are generally very inconclusive, given that in many Brazilian studies, all species are placed in the genus Trichodina. Similar problems were described by Van As and Basson (1987). Current methods to identify trichodinid species in fish in Brazil are better than those in the older studies included here.

\section{Pathology of trichodinids}

The pathology of trichodinid infection and the occurrence of host mortality events depend on factors such as the intensity of trichodinids, infection site, host age, pathogenicity of the etiological agent, and relationship to other infections or infestations by other organisms, in addition to the environmental conditions that can stimulate the infection and immunological conditions of the host.

Seasonality has an influence on the occurrence of trichodinids in fish in countries with temperate and cold climates because spring and winter are the seasons that are more favorable for multiplication of these ciliates (Hossain et al. 2008; Abdel-Baki et al. 2011; Yemmen et al. 2011; Özer et al. 2015). In Brazil, a large country, there is no pattern of seasonal occurrences given the regional differences in temperature and rainfall levels. In the northeastern region of the state of São Paulo, the prevalence of Trichodina sp. was found to increase in the spring and summer due to the increasing temperature and consequent stimulation of parasite reproduction and not because of the seasonality of rainfall levels (Schalch and Moraes 2005). In contrast, similar studies on fish in the same region found higher rates of parasitism in the winter (Tavares-Dias et al. 2001; Valladão et al. 2013). In the southern region of the country, Martins et al. (2010a) found Trichodina sp. in O. niloticus only in winter and spring, and the intensity and prevalence of parasites did not show any correlation to the seasonality of rainfall or water temperature. In the Amazon region, which has the climate of tropical forest, the dry and rainy seasons have a strong influence on the dynamics of parasite communities. Thus, Neves et al. (2013) reported that in A. ocellatus in Lake Pracuúba, the prevalence and intensity of Trichodina sp. was greater during the rainy season. However, the occurrence of trichodinids and the outbreak of diseases has a close relationship to the physiological and immunological conditions of the host, the management used, water quality conditions and the ecology of the specific species of parasite. These factors may provide conditions that favor multiplication of parasites to pathogenic levels (Ceccarelli et al. 1990; Palm and 
Dobberstein 1999; Garcia et al. 2009; Martins et al. 2010a, b; Valladão et al. 2014; Valladão et al. 2016a).

A water temperature of $29^{\circ} \mathrm{C}$ stimulated growth of Trichodina puytoraci, while a temperature of $18{ }^{\circ} \mathrm{C}$ inhibited growth. These antagonistic effects influenced the prevalence and intensity of infection by this trichodinid on Mugil cephalus from Tunisia (Yemmen et al. 2011). During the winter, higher rates of infection due to Trichodina spp. in Platichthys flesus were correlated with increased bacterial biomass, which in turn provided food for these parasites and supported their multiplication (Palm and Dobberstein 1999). Reduction of dissolved oxygen levels and addition of organic fertilizer favored reproduction of Trichodina sp. (Garcia et al. 2009), demonstrating that eutrophication levels, which can be measured from the degree of transparency of the water, may influence the levels of parasitism of these parasites.

In the coastal ecosystem of the Black Sea in Turkey, primary production peaks were a factor for the increased prevalence of Trichodina spp. in Merlangius merlangus. Moreover, nitrate, nitrite and phosphorus levels were shown to have synergistic effects on ciliate density (Ogut and Palm 2005). The growth of algae and bacteria in organically polluted (eutrophized) environments stimulated planktonic growth because of the availability of food, and these conditions stimulated the growth of parasites on the surface of their hosts (Ogut and Palm 2005). This study aimed to validate trichodinids as bioindicators, and thus, the field results can be extrapolated to fish farming.

In relation to the level of infestation, mild to moderate infestation by trichodinids may be asymptomatic and not cause macroscopic alterations (Valladão et al. 2014). In other cases, mortality and clinical signs may be observed; however, these signs may be nonspecific and common to other diseases (Jerônimo et al. 2011; Garcia et al. 2013; Valladão et al. 2013, 2014). Clinical signs among fish, such as swimming on the water surface, slowness, anorexia, darkening or alteration of skin pigmentation to bluishgray due to excessive mucus production, and peeling of the epithelium can be observed (Basson and Van As 2006; Abd El-Galil and Aboelhadidb 2012; Valladão et al. 2013). Thus, Schizothorax niger, with its skin and gills parasitized by $T$. heterodentata, showed lethargy and body pallor, along with excessive mucus secretion and hemorrhagic areas on the body (Dar et al. 2016). In P. lineatus, erratic swimming was correlated with impaired vision due to corneal lesions caused by T. heterodentata (Valladão et al. 2014). In $O$. niloticus, macroscopic signs of parasitism due to Paratrichodina africana consisted of pallid gills with multifocal whitish areas suggesting necrosis and the presence of a substance with a milky appearance (Valladão et al. 2013). These events may have been associated with secondary bacterial infection due to the abrasive action of the ciliate that favored penetration and multiplication of bacteria (Valladão et al. 2013).

In farmed cyprinid species (Figueira and Ceccarelli 1991), as well as Astronotus ocellatus and Symphysodon discus (Mohammadi et al. 2012), concurrent infections by monogeneans, I. multifillis and Trichodina sp. and by Argulus sp., monogeneans and Trichodina sp. (Tomec et al. 1995) were reported. Concurrent infection of trichodinids and monogeneans is common in farmed fish, where they may act with synergistic deleterious effects (Colorni and Diamant 2005). In Arapaima gigas, association of infection by Trichodina sp. (Fig. 2) and monogeneas Dawestrema sp. was responsible for mortality of $37 \%$ in a batch of fry (Araújo et al. 2009a). The relationship between trichodinids and other infections or infestations by other organisms has also been demonstrated, showing that coinfection by protozoans and bacteria increases the mortality rate among farmed fish. Infection by parasites increases the capacity for invasion by bacteria, may make hosts more susceptible to bacteriosis and may compromise humoral stimulation (Martins et al. 2011; Xu et al. 2012; Valladão et al. 2014). Hyperparasitism by trichodinid ciliates on the monogeneans Diplectanum aequans in the gills of Dicentrarchus labrax from southern Israel was also reported (Colorni and Diamant 2005).

A correlational study between diseases caused by parasites and host age was conducted on larvae and juveniles of $O$. niloticus in three fish farms in São Paulo and Minas Gerais (Valladão et al. 2016a). Among the larvae, low to moderate mean intensities of infection $(31.8 \pm 19.07$ parasites/fish and $197.67 \pm 202.24$ parasites/fish, respectively) were observed, compared to high infection among the juveniles (1132.60 \pm 949.71 parasites/fish), which presented a parasite intensity tenfold greater than that of the larvae. However, only the larvae presented lesions on the fins and eyes, which were characterized as areas of parasite suction, skin peeling and 
ulceration. The juveniles rarely presented lesions, and these primarily appeared in areas without scales, such as the head (Valladão et al. 2016a). Mortality among fish larvae was also reported by Eisa et al. (1985) and Valladão et al. (2014). In younger fish and those that had become debilitated by environmental factors, for example, the natural protection of the body surface is impaired and trichodinids find it easier to proliferate (Basson and Van As 2006). The high parasitism among juveniles (but with rare lesions) may be related to the influence of host age. However, the harmful effects on larvae, even when parasitism levels are low, are due to the absence of completely formed scales, which function as the first defense barrier against the entry of parasites.

Regarding the extent of damage caused by trichodinids, Basson and Van As (2006) stated that the different attachment structures and feeding habits of these parasites may give rise to different lesions. Recent studies have confirmed that the pathogenicity of these parasites varies between species and site of infection. Among the larvae of $O$. niloticus, lesions of different sizes and intensities of damage were found because of the presence of more than one species of trichodinid was involved in the infection (Valladão et al. 2016a). Although little is known about the genus Paratrichodina, Valladão et al. (2013) stated that pathological alterations caused by $P$. africana in $O$. niloticus showed that this species has significant pathogenic potential in intensive farming systems in net-cages.

Histopathological alterations may indicate that host exposure to trichodinids is either acute or chronic. Chronic alterations to the gills are characterized by hypertrophy and hyperplasia of epithelial cells, partial or total fusion of the secondary lamellae, hyperplasia of mucosal cells, inflammatory infiltration of eosinophils and mononuclear cells, interstitial hemorrhage, congestion and necrosis (Valladão et al. 2013; Dar et al. 2016). However, lesser alterations such as subepithelial edema and mild inflammatory reactions were recorded in acute infestations due to T. heterodentata, which caused mortality among $P$. lineatus larvae (Valladão et al. 2014).

\section{Methodologies for identification and quantitative and qualitative evaluation}

Taxonomic identification of trichodinids is achieved through a set of characteristics, including the skeletal, nuclear and cilia structures of the parasites, after subjecting the material to specific preparations and stains. Within the Trichodinidae, differentiation between genera is achieved using the morphological characteristics of the denticles of the adhesive disk and the adoral spiral ciliature, which may comprise spirals of cilia with complete turns, more than or less than $360^{\circ}$, as shown in Table 2 (Basson and Van As 1989).

A variety of characteristics have been evaluated to identify species of trichodinids. However, with time and in accordance with more recent studies, the structure of the adhesive disk and the morphology of the denticles have become the reference structures (Gaze and Wootten 1998; Basson and Van As 2006). According to Van As and Basson (1987), the revolution in the taxonomy of the trichodinids occurred in 1958, when Lom proposed using impregnation with silver, adapted from Klein's previously established method.

The ring of denticles that forms the adhesive disk is the only example of a support system in single-cell

Table 2 Main characteristics that differentiate the genera within the family Trichodinidae, for the species that occur in freshwater and saltwater fish, in accordance with Basson and Van As (1989)

\begin{tabular}{|c|c|c|}
\hline \multirow[t]{2}{*}{ Genders } & \multicolumn{2}{|l|}{ General morphological features } \\
\hline & Adoral ciliary spiral & Denticles in the adhesive disk \\
\hline Trichodina & Lengths ranging from $360^{\circ}-540^{\circ}$ & Denticles consisting of blades, central parts and rays \\
\hline Paratrichodina & Arch makes a turn of $150^{\circ}-280^{\circ}$ & Well-developed rays and wedged only by central part \\
\hline Tripartiella & Arch makes a turn of $180^{\circ}-290^{\circ}$ & Denticles with a delicate central part \\
\hline Trichodinella & Arch of $180^{\circ}-270^{\circ}$ & $\begin{array}{l}\text { Denticles with a delicate central part; ray forms a } \\
\text { delicate hook curved along central part }\end{array}$ \\
\hline Dipartiella & Arch of about $270^{\circ}$ & Consisting only of blades and weakly developed central parts \\
\hline
\end{tabular}


organisms that is analogous to the spinal column. It is responsible for lesions in the host and functions as a suction structure (Basson and Van As 2006). These structures are evaluated after sample preparation using silver nitrate $\left(\mathrm{AgNO}_{3}\right)$ by means of Klein's technique (Klein 1958; Lom and Dykova 1992). Smears that have been dried at room temperature are impregnated with an aqueous solution of $2 \%$ silver nitrate for $8 \mathrm{~min}$, followed by exposure to ultraviolet light for 1-2 h (Eiras et al. 2006).

The following characteristics of the trichodinid parasites are evaluated: body diameter, diameter of the adhesive disk, width of the membrane border, diameter of the denticle ring, number of denticles, number of radial pins per denticle, denticle length, lamina length, width of the central portion, radial length and palm length. The denticles are solid and composed of three regions: the distal lamina, central part and proximal radius (Arthur and Margolis 1984; Basson and Van As 2006).

Body diameter measurement comprises the diameter of the adhesive disk plus the thickness of the membrane border (Basson and Van As 1989). However, this measurement should be made cautiously, as there is a certain degree of variability and deformation of the structure of the adhesive disk (Van As and Basson 1989). Gaze and Wootten (1998) reviewed the species of Trichodina among freshwater fish in England and warned about errors in the measured values of the adhesive disk structures. Moreover, since skeletal growth is a means of determining the age of trichodinids, a given population will include individuals with half the number of skeletal structures. Thus, these authors recommend that these should be excluded from species evaluations.

Measurements of parasites are generally made by means of images obtained under an ordinary optical microscope. It is recommended that schematic drawings of denticles are presented in each published study. Electron microscopy may aid in identifying and making finer morphological descriptions of the structures of trichodinids (Basson and Van As 2006).

The characteristics of the nuclear apparatus are evaluated using mucus smears or gills containing the parasites that have previously been fixed in methanol, using Giemsa solution (one drop of Giemsa for $1 \mathrm{~mL}$ of distilled water, with exposure for 2-3 h) (Ghiraldelli et al. 2006; Jerônimo et al. 2012; Pádua et al. 2012b), or by means of smears stained with Gömöri's trichrome (Miranda et al. 2012). The nuclear apparatus consists of a macronucleus that usually has an ellipsoid or horse-saddle format and a micronucleus that is only visible in some species (Basson and Van As 2006). The macronucleus shape, external diameter, thickness and length of sections between the ends are measured (Van As and Basson 1989).

The intensity of parasitism is determined from the number of parasites in each infected host (Bush et al. 1997). The methods for quantifying trichodinids are based on direct or indirect counting. In direct evaluations, the total number of parasites is counted, either from mucus smears from the body surface of each host, prepared on glass slides (Jerônimo et al. 2012; Zago et al. 2014; Ikefuti et al. 2015; Özer et al. 2015) or the number on one side of the host's body (Madsen et al. 2000). To analyze the gills, the arches are collected and placed between a slide and cover slip (Jerônimo et al. 2012; Ikefuti et al. 2015). The fresh material can be analyzed under an ordinary optical microscope after drying at room temperature (Valladão et al. 2013; Valladão et al. 2016a) or after fixing in $70 \%$ alcohol (Zago et al. 2014). In fresh preparations, the high mobility of the parasites, the cilia and the bell or circular shape can be observed, depending on the position of the parasite (Noga 2010; Özer et al. 2015).

Another method of quantifying trichodinids is to directly use the total count of parasites present on the body surface of the hosts, as recommended by Valladão et al. (2016a) for the larvae of O. niloticus, and by Fernandes et al. (2011) for tadpoles of Rhinella pombali. However, to count trichodinids on the body surface of larger fish, a standard sampling area must be defined, or a single gill arch must be selected for analysis (Sommerville et al. 2016).

Parasites can be quantified indirectly using a Sedgwick-Rafter or MacMaster chamber or by means of a hemocytometer from mucus or gill samples conserved in formalin (Fernandes et al. 2011; Jerônimo et al. 2011; Basson et al. 1983). Each fish can also be placed in an individual flask with an appropriate amount of water and shaken to detach the trichodinids (Sommerville et al. 2016). In this method, the sample should be homogenized to remove aliquots of $1.0 \mathrm{~mL}$ for counting in a Sedgewick-Rafter chamber, which is the method that is currently used most often. After the total volume of stored solution has been determined with a measuring beaker, the total 
number of parasites in the sample is calculated (Fernandes et al. 2011; Jerônimo et al. 2011). It is recommended that several subsamples be counted (at least three) to provide a more appropriate estimated value (Sommerville et al. 2016). In counting the three aliquots in a Sedgwick-Rafter chamber, the volume is $3.0 \mathrm{~mL}$. Thus, the average from the number of trichodinids in the three aliquots should be obtained by multiplying by the total number of parasites quantified.

Another method was proposed by Garcia et al. (2009), in which slides prepared from scrapings of mucus are examined and the number of parasites found per field at a magnification of $10 \times$ under an ordinary optical microscope is estimated from zero to five parasites (scores). Indirect quantification can also be performed by counting the mean number of parasites in five microscope fields of fresh samples (Abd El-Galil and Aboelhadidb 2012) or determined according to categories and levels of infection, as suggested by Madsen et al. (2000): 0 parasites, category $0 ; 1-10$ parasites, category $1 ; 11-100$ parasites, category $2 ; 100-1000$ parasites, category 3; and 1000-10,000 parasites, category 4; or as suggested by Rach et al. (2000): 0 (parasite does not exist); 1-10 (low); 11-20 (moderate); $\geq 21$ (high).

For studies of the efficacy of medications, it has been recommended that quantification methods should be predetermined and followed rigorously during the trial. In addition, especially in these cases, counts should be made by a single trained handler. In in vivo tests, when the samples are not fixed and counted immediately, quantified trichodinids should be classified as alive, moribund or dead (Sommerville et al. 2016).

Another method for identifying trichodinids is histopathological analysis using ordinary optical microscopy and electron microscopy, which also contributes to greater comprehension of the aggression caused by trichodinids at different attachment sites and of host responses (Palm and Dobberstein 1999; Valladão et al. 2014; Özer et al. 2015). In histological sections, depending on the orientation of the sections through the parasites, trichodinids may appear hemispherical, bag-shaped or flattened-cylindrical. The macronucleus may be visible as a horseshoe shape, along with some elements of the adhesive disk and cilia (Bruno et al. 2006).

One problem in quantifying trichodinids is the method used for sacrificing fish prior to sample collection. This involves the use of an overdose of anesthetic and should be evaluated or tested beforehand to ascertain whether the anesthetic or solvent used might destroy parasites in the host (Sommerville et al. 2016).

Due to the difficulty of differentiating similar trichodinid species solely based on morphological data, molecular identification methods are necessary for identification (Tang et al. 2017). Gong et al. (2006) performed the first investigation on phylogenetic relationships using small subunit ribosomal RNA (SSU-rDNA) sequences for Trichodinidae species using $T$. nobilis, $T$. heterodentata, $T$. reticulata and Trichodinella myakkae, showing that Trichodinella were nested within the Trichodina. Furthermore, $T$. reticulata, a Trichodina species with granules in the center of the adhesive disc, branched separately from its congeners $T$. nobilis and T. heterodentata, which are trichodinids without such granules (Gong et al. 2006). Utz and Eizirik (2007) and Zhan et al. (2009) questioned the results of Gong et al. (2006) in Trichodinella. Recent studies using SSU-rDNA for Trichodinella sp. and Trichodina pectenis reported that Trichodinella is nested within Trichodina (Zhan et al. 2013). However, according to Tang et al. (2013) the genus Trichodina is paraphyletic when species of Trichodinella are included in the analyses. Very recently, Tang et al. (2017) sequenced, for the first time, the SSU rDNA of a new species of trichodinid: Trichodina pseudoheterodentata of the channel catfish Ictalurus punctatus. Phylogenetic analysis revealed that the genetic distances among the new species and similar species reached interspecific levels, validating the identification of this new species and its placement in the genus Trichodina. There are limited molecular data for trichodinids because many species have not been sequenced, and the effectiveness of DNA-based identification of species relies on the availability of sequences in public databases for comparison (Zhan et al. 2013; Tang et al. 2017); therefore, there is not yet a consensus about the relationships based on molecular phylogenetics.

\section{Methods for prevention and control of trichodinids}

Trichodinids have the capacity for rapid multiplication. Diagnosis must be made quickly so that appropriate management can be instituted, or, as a second 
course of action, emergency treatment can be administered before these parasites can cause high mortality (Basson and Van As 2006). Since outbreaks of infection due to trichodinids indicate environmental imbalance and the incapacity of the host to respond, treatment alone is insufficient to solve the problem. Improvements to management and water quality conditions, along with use of preventive measures, are of prime importance. Reduction of the concentration of organic matter is an effective preventive method against these ciliates (Basson and Van As 2006; Buchmann 2013).

Another preventive strategy is to supply feed with vitamin supplementation (consisting of $300-500 \mathrm{mg}$ of vitamin $\mathrm{C} / \mathrm{kg}$ of dry feed) before handling the fish and before the annual cold period, as supplementation may contribute to increasing the immune response of fish against parasites (Martins et al. 2002). Among the larvae of $O$. niloticus that were given feed containing $300 \mathrm{mg}$ of vitamin $\mathrm{E} / \mathrm{kg}$, there was also a reduction in the intensity of trichodinids (Cavichiolo et al. 2002).

Various products for combating trichodinids have already been evaluated, including salts such as copper sulfate and potassium permanganate; glacial acetic acid; coccidiostatic agents such as toltrazuril; anthelmintics such as bithionol; insecticides such as teflubenzuron; commercial disinfectants (Madsen et al. 2000); and aldehydes such as formol and sodium chloride $(\mathrm{NaCl})$. The concentrations used and the exposure times are very different and depend on the sensitivity of the fish species, water quality, dose, length of exposure and product used (Table 3 ).

Copper sulfate is administered only by means of immersion and is actively absorbed throughout the exposure period. Increased salinity and diminished $\mathrm{pH}$ of the water and vehicle result in concentrations of greater toxicity, e.g., freshwater fish are more sensitive to copper sulfate than are saltwater fish (Harms 1996). This form of chemotherapy presents proven action against protozoa, since it was effective for achieving a 100\% reduction of Trichodina spp. in freshwater trout (Balta et al. 2008) but not in the fry of the saltwater turbot Colistium nudipinnis (Diggles 2000).

Acetic acid is the main component of vinegar, but the concentrations used in aquaculture are based on commercial glacial acetic acid, which is indicated against ectoparasites (Harms 1996). Toltrazuril is a coccidiostatic compound with wide-ranging action against protozoa. Because it is commercially available in a water-soluble form and it has ready action against host cells, it was tested against the ectoparasites of fish (Mehlhorn et al. 1988). Bithionol is an anthelmintic that is directed towards trematodes and cestodes, but because of its good action on recirculation systems, it can be used on species of protozoa (Madsen et al. 2000). However, Madsen et al. (2000) emphasized that bithionol has a narrow safety margin and that the dynamics of its residues and metabolites in the musculature of fish exposed to it are unknown.

Potassium permanganate is an oxidizing agent that reacts with organic matter. Thus, if applied to fishfarm ponds, it reacts with bacteria, algae, organisms in sediments, suspended particles and fish. For this reason, it is used as a treatment for ectoparasitic and fungal diseases (Lay 1971). Teflubenzuron is an insecticide that inhibits the production of chitin and thus selectively controls arthropod and crustacean crop pests. For this reason, its toxicity towards aquatic invertebrates is high (Harms 1996). Therefore, because of its low toxicity towards vertebrates and because it acts on chitin, which is also present in the structure of the adhesive disk of trichodinids, it was tested against this ciliate (Ikefuti et al. 2015) (Table 3). In another study, hydrogen peroxide did not show any positive results against trichodinids (Rach et al. 2000).

Disinfectants such as formaldehyde are commercially available in the form of a $37-40 \%$ aqueous solution known as formalin. It has broad-spectrum action against ectoparasites (Burka et al. 1997; FajerÁvila et al. 2003) and a good cost-benefit relationship if correctly applied, but it may be toxic or compromise the integrity of the epithelium and production of mucus in exposed fish (Buchmann et al. 2004). Recently, Valladão et al. (2016a) demonstrated that lower concentrations of formalin $(0.25 \mathrm{~mL} / \mathrm{L})$, which are commonly used on farmed tilapias, are sufficient to eliminate Trichodina spp. in larvae. Thus, high concentrations cannot be justified from health and environmental standpoints. Furthermore, in these baths, salts were combined with formalin to stimulate mucus production (Valladão et al. 2016a).

To reduce the use of chemotherapeutic agents within aquaculture, alternative methods such as the use of phytotherapeutic agents are being tested. Plants with bioactive properties form an important source of new biologically active compounds for treating fish diseases, especially parasitic diseases (Kumar et al. 
Table 3 Chemotherapeutic agents used for controlling Trichodinidae in fish of zootechnical interest

\begin{tabular}{|c|c|c|c|}
\hline Product & Species (size and weight ${ }^{\mathrm{a}}$ ) & Dosage (dose and length of exposure) & References \\
\hline \multirow[t]{5}{*}{ Salt $(\mathrm{NaCl})$} & Ctenopharyngodon idella & $0.7 \%$-bath for $21-24 \mathrm{~h}$ & Willomitzer (1980) \\
\hline & $\begin{array}{l}\text { Hypophthalmichthys molitrix and } \\
\text { Cirrhinus mrigala }\end{array}$ & $30 \mathrm{mg} / \mathrm{L}$ — bath for $10 \mathrm{~min}$ & Singhla et al. (1986) \\
\hline & Arapaima gigas (fry) & $15 \mathrm{~g} / \mathrm{L}$-bath for $5 \mathrm{~min}$ & Guerra (2002) \\
\hline & Oreochromis niloticus & $3 \%$-bath for $10 \mathrm{~min}$ & Vargas et al. (2003) \\
\hline & $\begin{array}{l}\text { Oncorhynchus mykiss, Salvelinus } \\
\text { fontinalis, Salmo trutta fario (fry } \\
1.0 \pm 0.2 \mathrm{~g} \text { and juveniles } \\
40 \pm 0.7 \mathrm{~g} \text { ) }\end{array}$ & $20 \mathrm{~g} / \mathrm{L}$ — bath for $20 \mathrm{~min}$ & Balta et al. (2008) \\
\hline \multirow[t]{13}{*}{ Formalin } & Ctenopharyngodon idella & $\begin{array}{l}1: 2500 \text { — bath for } 60 \mathrm{~s} \\
\text { (mortality rate of } 23 \% \text { among fish) }\end{array}$ & Willomitzer (1980) \\
\hline & $\begin{array}{l}\text { Hypophthalmichthys molitrix and } \\
\text { Cirrhinus mrigala }\end{array}$ & $0.004-0.006 \mathrm{mg} / \mathrm{L}$ — bath for $10 \mathrm{~min}$ & Singhal et al. (1986) \\
\hline & Oreochromis niloticus & $250 \mathrm{ppm}$-bath for $35-40 \mathrm{~min}$ & Neguenga (1988) \\
\hline & Astyanax bimaculatus & $0.25 \mathrm{~mL} / 20 \mathrm{~L}$ — bath for $72 \mathrm{~h}$ & Rocha et al. (1993) \\
\hline & Anguilla anguilla $(1-30 \mathrm{~g} ; 70-250 \mathrm{~g})$ & $75 \mathrm{ppm}$-bath for $3 \mathrm{~h}$ & Madsen et al. (2000) \\
\hline & Colistium nudipinnis (fry $4.1-8.9 \mathrm{~cm}$ ) & $\begin{array}{l}200 \mathrm{ppm} \text { - bath for } 30 \mathrm{~min} \\
200 \mathrm{ppm} \text { - bath for } 1 \mathrm{~h}\end{array}$ & Diggles (2000) \\
\hline & Arapaima gigas (fry) & $0.25 \mathrm{~mL} / \mathrm{L}$ — bath for $20 \mathrm{~min}$ & Guerra (2002) \\
\hline & Arapaima gigas & $\begin{array}{l}\text { Eggs: } 100 \mathrm{mg} / \mathrm{L} \text { - bath for } 30 \mathrm{~min} \\
3 \times \text { day }\end{array}$ & Sebrae (2013) \\
\hline & & Fry: $50-100 \mathrm{ppm}-$ bath for $1 \mathrm{~h}$ & \\
\hline & Oreochromis niloticus & $250 \mathrm{ppm}$-bath for $60 \mathrm{~min}$ & Vargas et al. (2003) \\
\hline & $\begin{array}{l}\text { Oncorhynchus mykiss, Salvelinus } \\
\text { fontinalis, Salmo trutta fario (fry } \\
1.0 \pm 0.2 \mathrm{~g} \text { and juveniles } \\
40 \pm 0.7 \mathrm{~g} \text { ) }\end{array}$ & $0.10-0.15 \mathrm{~mL} / \mathrm{L} —$ bath for $60 \mathrm{~min}$ & Balta et al. (2008) \\
\hline & Not specified & $25-40 \mathrm{ppm}$ - bath for indeterminate time & Abowei et al. (2011) \\
\hline & Oncorhynchus mykiss & $250 \mathrm{ppm}$ - bath for $24 \mathrm{~h}$ & $\begin{array}{l}\text { Khoshnood and Khoshnood } \\
\text { (2014) }\end{array}$ \\
\hline Formalin + salt $(\mathrm{NaCl})$ & Oreochromis niloticus & $0.5 \mathrm{~mL} / \mathrm{L}+1 \%$-bath for $15 \mathrm{~min}$ & Valladão et al. (2016a) \\
\hline Copper sulfate & Oreochromis niloticus & $\begin{array}{l}0.03-0.06 \mathrm{mg} / \mathrm{L} \text { - bath for } 48 \mathrm{~h} \\
0.3-0.09 \mathrm{mg} / \mathrm{L} \text { - bath for } 24 \mathrm{~h}\end{array}$ & Abdel-Meguid (2001) \\
\hline Potassium permanganate & Ctenopharyngodon idella & $1: 1.000$ only dipping the fish into it & Willomitzer (1980) \\
\hline \multirow[t]{2}{*}{ Acetic acid } & $\begin{array}{l}\text { Hypophthalmichthys molitrix and } \\
\text { Cirrhinus mrigala }\end{array}$ & $0.001 \mathrm{mg} / \mathrm{L}$ — bath for $10 \mathrm{~min}$ & Singhal et al. (1986) \\
\hline & $\begin{array}{l}\text { Oncorhynchus mykiss, Salvelinus } \\
\text { fontinalis, Salmo trutta fario (fry } \\
1.0 \pm 0.2 \mathrm{~g} \text { and juveniles } \\
40 \pm 0.7 \mathrm{~g} \text { ) }\end{array}$ & $10 \mathrm{~mL} / \mathrm{L}$-bath for $3 \mathrm{~min}$ & Balta et al. (2008) \\
\hline \multirow[t]{2}{*}{ Toltrazuril } & Not specified & $\begin{array}{l}10 \mu \mathrm{g} / \mathrm{ml} \text { - bath for } 2-4 \mathrm{~h} \text {, } \\
\text { eliminated most parasites } \\
50 \mu \mathrm{g} / \mathrm{mL} \text { - bath for } 20 \mathrm{~min} \text {, } \\
\text { for major infections }\end{array}$ & Mehlhorn et al. (1988) \\
\hline & Piaractus mesopotamicus & $\begin{array}{l}3.0 \mathrm{mg} / \mathrm{L} \text { - bath for } 1 \mathrm{~h} \text {, on } 5 \text { consecutive } \\
\text { days }\end{array}$ & Carraschi et al. (2014) \\
\hline Bithionol & Anguilla anguilla $(1-30 \mathrm{~g} ; 70-250 \mathrm{~g})$ & $0.1 \mathrm{ppm}$ & Madsen et al. (2000) \\
\hline
\end{tabular}


Table 3 continued

\begin{tabular}{|c|c|c|c|}
\hline Product & Species (size and weight ${ }^{\mathrm{a}}$ ) & Dosage (dose and length of exposure) & References \\
\hline \multirow[t]{2}{*}{ Teflubenzuron } & Piaractus mesopotamicus & $\begin{array}{l}50 \mathrm{mg} / \mathrm{L} \text { - bath for } 2 \mathrm{~h} \text { for } 5 \text { days between } \\
24-\mathrm{h} \text { intervals }\end{array}$ & Ikefuti et al. (2015) \\
\hline & Oreochromis niloticus & $\begin{array}{l}50 \mathrm{mg} / \mathrm{L} \text { - bath for } 1 \mathrm{~h} \text { for } 5 \text { days between } \\
24-\mathrm{h} \text { intervals }\end{array}$ & Ikefuti et al. (2015) \\
\hline \multirow[t]{2}{*}{$\begin{array}{l}\text { Compound based on } \\
\text { peroxide }\end{array}$} & Anguilla anguilla $(1-30 \mathrm{~g} ; 70-250 \mathrm{~g})$ & $\begin{array}{l}25 \mathrm{ppm} \text { (supplemented with another } \\
20 \mathrm{ppm} \text { ) }\end{array}$ & Madsen et al. (2000) \\
\hline & Oreochromis niloticus & $\begin{array}{l}2 \mathrm{ppm} \text { - bath for } 40 \mathrm{~min} \\
5 \mathrm{ppm} \text {-bath for } 20 \mathrm{~min}\end{array}$ & Marzouk et al. (2013) \\
\hline
\end{tabular}

$1 \mathrm{ppm}=0.001 \mathrm{~mL} / \mathrm{L} ; 1 \%=1 \mathrm{~g} / 100 \mathrm{~mL}$

${ }^{\text {a }}$ When stated

2012; Wu et al. 2011; Zhang et al. 2013). Moreover, phytotherapeutic agents appear to have fewer harmful effects on human health and the environment (Chu et al. 2010). Thus, extracts and essential oils are used, especially against $I$. multifiliis (Yao et al. 2011; Yi et al. 2012; Fu et al. 2014), but few studies have been directed towards trichodinids, and most studies were conducted in northeastern Africa.

Administration of Allium sativum (garlic) in the form of immersion baths controls infestations by trichodinids in various species of fish through its main active agent, allicin. Madsen et al. (2000) showed that $200 \mathrm{mg} / \mathrm{L}$ of crude or macerated extract of A. sativum in 24-h baths $\left(25^{\circ} \mathrm{C}\right)$ reduced the intensity of infection by Trichodina jadranica in the eel Anguilla anguilla. For O. niloticus, the lethal concentration of garlic oil extracted directly from the bulb was $61.86 \mathrm{ppt}$, which is many orders of magnitude lower than the effective dose. Thus, this phytotherapeutic agent can be used on fish with a good safety margin (Abd Abd El-Galil and Aboelhadidb 2012). Therefore, for larvae of $O$. niloticus that were cultivated in the laboratory, prevention of infection by $T$. heterodentata, $T$. compacta and Gyrodactylus can be achieved with 2.0, 2.5 and $3.0 \mathrm{ppt}$ A. sativum in baths lasting up to $4 \mathrm{~h}$ (Abd Abd El-Galil and Aboelhadidb 2012). Baths containing $3 \mathrm{ppt}$ A. sativum oil applied for $60 \mathrm{~min}$ and containing $300 \mathrm{mg} / \mathrm{L}$ crushed $A$. sativum applied for an indeterminate time period were also shown to be effective for larvae in an incubator and for fry in excavated ponds (Abd Abd El-Galil and Aboelhadidb 2012). Extracts of A. sativum and Terminalia catappa (almond tree) administered in the form of immersion baths, both at a concentration of $800 \mathrm{mg} / \mathrm{L}$, eliminated $100 \%$ of Trichodina sp. in O. niloticus after 2 days of application (Chitmanat et al. 2005). However, reinfection occurred 14 days after treatment, and this was attributed to deterioration of water quality because the extracts used increased the concentration of organic matter (Chitmanat et al. 2005).

In addition to $8.0 \mathrm{~g} / \mathrm{kg}$ of $A$. sativum extract, $4.5 \mathrm{~g} /$ $\mathrm{kg}$ of Artemisia vulgaris extract in feed given to $O$. niloticus exhibited an antiparasitic effect against Trichodina sp. but gave rise to mortality rates of 20 and $16 \%$, respectively (Noor El Deen and Mohamed 2010). Use of Camellia sinensis extract (green tea) in therapeutic baths at a concentration of $0.05 \%$ for $15 \mathrm{~min}$ or $0.09 \%$ for $5 \mathrm{~min}$ reduced the number of parasites on the skin and fins of $O$. niloticus by 80 and 95\%, respectively (Noor El Deen 2010). Bioactive compounds such as chelidonin, chelerythrine and sanguinarine, isolated from the plant Chelidonium majus, demonstrated $100 \%$ effectiveness for elimination of Trichodina sp. from Parabramis pekinensis. These compounds are thus more effective than formalin (Yao et al. 2011). Other phytotherapeutic agents such as ginger Zingiber officinale (Abo-Esa 2008) and the plant sheh el-baathran have also been evaluated (Aboud 2010).

Sodium chloride (salt) is a product with many functions within aquaculture. It acts against parasites of the gills and skin but also functions as an agent for reducing the effects of nitrite poisoning, stimulating mucus production and reducing stress due to routine handling (Francis-Floyd 1995; Valladão et al. 2016a). The effects of common salt on fish, and on parasites, are determined through concentration and duration of exposure. Fish such as the tilapia $O$. niloticus, $C$. macropomum and $P$. mesopotamicus are more resistant than species of Siluriformes. For this reason, a 
quick test on a few fish should be performed before using salt to treat larger numbers of fish (Neguenga 1988; Francis-Floyd 1995). For farmed O. niloticus, Neguenga (1988) recommended that $25 \mathrm{~g} / \mathrm{L}$ of salt should be used in 15-min baths every two months in the tank to prevent reinfestations due to Trichodina sp. Use of 40-100 $\mathrm{g}$ of salt $/ \mathrm{m}^{3}$ in three treatments at 1-day intervals was also recommended for controlling infestations due to $P$. pillulare, Trichodina sp., monogeneans, Argulus sp. and Dolops sp. (Martins et al. 2002) (Table 3). Since controlling trichodinids using sodium chloride is relatively easy, the use of other products should be evaluated cautiously (Garcia et al. 2013), if only because most have not been approved by the Brazilian Ministry of Agriculture, Fisheries and Supply (MAPA).

Currently, in Brazil, there are 29 veterinary products that have been approved for use in aquaculture, of which six are antibiotics (e.g., florfenicol and terramycin) and four are antiparasitic agents (e.g., diflubenzuron and trichlorfon). Two other products with active agents not clearly specified have an indication for Trichodina sp. (see in SINDAN 2016). Despite the small number of products that are legally available for aquaculture in Brazil, a great variety of chemical products for which the lethal and clinical concentrations, length of exposure, waiting period and environmental impact have not yet been defined are currently being used there (Valladão et al. 2015). Therefore, although different studies conducted in Brazil have demonstrated that some chemotherapeutic and phytotherapeutic agents present antiparasitic effectiveness, their use has not been approved through legislation, and use of these products is limited. These products should be used sparingly.

\section{Conclusion}

Advances in studies of the biodiversity and molecular identification of Trichodinidae will contribute to knowledge of the epidemiology of these ciliate protozoa in different fish-farming systems used in South America. Studies correlating trichodinid species in hosts with specific pathological alterations observed in fish must be expanded to classify the species that have the greatest pathogenic potential for fish farmed in South America. From this knowledge, targeted control and prevention protocols of greater efficiency must be established. Likewise, new studies should correlate the occurrence of these protozoa with fishfarming conditions (stress factors, water quality, seasonality, fish age, etc.) to elucidate the critical points in each intensive production system. In addition, studies of treatments against trichodinids for farmed species in South America should be conducted to support and encourage approval of medications for use in aquaculture in Latin America.

For the production sector in South America, the focus should be on production systems that are more sustainable, with biomass stocked at tolerable limits that indicate wellbeing among the farmed fish, along with adoption of prophylactic management at all stages of farming, which will contribute to diminishing the pressure of parasites on fish. Early diagnosis and preventive actions must be implemented, rather than curative treatment, particularly regarding production of tilapia fry, for which problems relating to trichodinids are more severe and transferred to fish at the fattening stage. Therefore, there is a need to adopt biosafety protocols within fish farming. These not only require adjustment of farming densities to appropriate levels but also adjustments to feeding rates and genetic improvement of native species to increase their production and productivity. Biosafety in South America is still at an initial stage, and there is still a need for more precise information regarding disease transmission caused by trichodinid species, along with eradication of these parasites from farmed fish.

Acknowledgements We thank Daniel Chaves Webber, analyst at Embrapa Fishery and Aquaculture, for drawing up the cartogram presented in this document; National Council for Research and Technological Development (CNPq, Brazil) for its technical support given to Dr. M. Tavares-Dias; and SEBRAE (Brazilian Micro and Small Business Support Service), CNPq (Amazon Pirarucu Project) and Embrapa (Project MP2-01/2012) for financial support.

\section{References}

Abd El-Galil MAA, Aboelhadidb SM (2012) Trials for the control of trichodinosis and gyrodactylosis in hatchery reared Oreochromis niloticus fries by using garlic. Vet Parasitol 185:57-63. doi:10.1016/j.vetpar.2011.10.035

Abdel-Baki AS, Sakran T, Fayed H, Zayed E (2011) Trichodina fahaka (Ciliophora: Peritrichia) in Tetradon fahaka from Nile River, Egypt: Seasonality and histopathology. Sci Res Essays 6:1583-1587. doi:10.5897/SRE10.1046 
Abdel-Meguid M (2001) Trichodiniasis as a cause of mortality among infected Tilapia zillii with special emphasis on its control using Earthtec ${ }^{\text {tm }}$. Egypt J Aquat Biol Fish 5:95-104

Abo-Esa JFK (2008) Study on some ectoparasitic diseases of catfish, Clarias gariepinus with their control by ginger, Zingiber officiale. Mediterr Aquac J 1:1-9

Aboud OAE (2010) Application of some Egyptian medicinal plants to eliminate Trichodina sp. and Aeromonas hydrophila in tilapia (Oreochromis niloticus). Researcher 2:1-5

Abowei JFN, Briyai OF, Bassey SE (2011) A review of some basic parasite diseases in culture fisheries flagellids, dinoflagellides and ichthyophthriasis, ichtyobodiasis, coccidiosis trichodiniasis, heminthiasis, hirudinea infestation, crustacean parsite and ciliates. $\mathrm{Br} \mathrm{J}$ Pharm Toxicol $2: 213-226$

Alcántara-Bocanegra F, Verdi-Olivares L, Murrieta-Morey G, Rodríguez-Chu L, Chu-Koo FW, Águila-Pizarro MD (2015) Parásitos de alevinos de gamitana (Colossoma macropomum) y paco (Piaractus brachypomus) cultivados en el C.I. Quistococha, Loreto, Perú. Cienc Amazónica 5:42-49

Araújo CS, Tavares-Dias M, Gomes ALS et al (2009a) Infecções parasitárias e parâmetros sanguíneos em Arapaima gigas Schinz, 1822 (Arapaimidae) cultivados no estado do Amazonas, Brasil. In: Tavares-Dias M (org.) Manejo e Sanidade de Peixes em Cultivo. Embrapa Amapá, Macapá, pp 389-425

Araújo CSO, Gomes AL, Tavares-Dias M, Andrade SMS, Belem-Costa A, Borges JT et al (2009b) Parasitic infections in pirarucu fry, Arapaima gigas Schinz, 1822 (Arapaimatidae) kept in a semi-intensive fish farm in Central Amazon, Brazil. Vet Arh 79:499-507

Arthur JR, Margolis L (1984) Trichodina truttae Mueller, 1937 (Ciliophora: Peritrichida), a common pathogenic ectoparasite of cultured juvenile salmonid fishes in British Columbia: redescription and examination by scanning electron microscopy. Can J Zool 62:1842-1848. doi:10. 1139/z84-268

Asmat GSM, Hafizuddin AKM, Habib MMA (2003) Trichodina sythetenis sp. n. (Ciliophora: Trichodinidae) from the Mud Perch, Nandus nandus (Hamilton-Buchanan, 1822) (Nandidae) in Sylhe. Pak J Biol Sci 6:1774-1777

Ayroza DMMR, Garcia F, Ayroza LMS et al (2014) Environmental conditions, fish disease, management and economic evaluation of tilapia cages in a Brazilian hydroelectric reservoir. In: Walkefield R (org.) Tilapia: biology, management practices and human consumption. Nova Science Publishers, New York, pp 119-145

Azevedo TMP, Martins ML, Bozzo FR, Moraes FR (2006) Haematological and gill responses in parasitized tilapia from Valley of Tijucas River, SC, Brazil. Sci Agric 63:115-120. doi:10.1590/S0103-90162006000200002

Balta F, Kayis S, Altinok I (2008) External protozoan parasites in three trout species in the Eastern Black Sea region of the Turkey: intensity, seasonality, and their treatments. Bull Eur Ass Fish Pathol 28:157-162

Basson L, Van As JG (1989) Differencial diagnosis of the genera in the family Trichodinidae (Ciliophora: Peritrichida) with the description of a new genus ectoparasitic on freshwater fish from southern Africa. Syst Parasitol 13:153-160. doi:10.1007/BF00015224
Basson L, Van As JG (2006) Trichodinidae and other ciliophorans (Phylum Ciliophora). In: Woo PTK (ed) Fish diseases and disorders. CAB International, Wallingford, pp 154-182

Basson L, Van As JG, Paperna I (1983) Trichodinid ectoparasites of cichlid and cyprinid fishes in South Africa and Israel. Syst Parasitol 5:245-257. doi:10.1007/BF00009159

Békési L (1992) Evaluation on data of ichthyopathological analysis in the Brazilian northeast. J Braz Assoc Adv Sci 44:400-403

Bittencourt LS, Pinheiro DA, Cárdenas MQ, Fernandes BM, Tavares-Dias M (2014) Parasites of native Cichlidae populations and invasive Oreochromis niloticus (Linnaeus, 1758) in tributary of Amazonas River (Brazil). Braz J Vet Parasitol 23:44-54

Bravo S, Almonacid C, Oyarzo C, Silva MT (2007) The parasite fauna of Galaxias maculatus in the estuary of Maullin River, Chile. Bull Eur Ass Fish Pathol 27:10-17

Bruno DW, Nowak B, Elliott DG (2006) Guide to the identification of fish protozoan and metazoan parasites in stained tissue sections. Dis Aquat Org 12:1-36. doi:10.3354/dao 070001

Buchmann K (2013) Impact and control of protozoan parasites in maricultured fishes. Parasitology 142:168-177. doi:10. 1017/S003118201300005X

Buchmann K, Bresciani J, Jappe C (2004) Effects of formalin treatment on epithelial structure and mucous cell densities in rainbow trout, Oncorhynchus mykiss (Walbaum), skin. J Fish Dis 27:99-104. doi:10.1111/j.1365-2761.2003.005 19.x

Burka JF, Hammell KL, Horsberg TE, Johnson GR, Rainnie DJ, Speare DJ (1997) Drugs in salmonid aquaculture-a review. J Vet Pharmacol Ther 20:333-349. doi:10.1046/j. 1365-2885.1997.00094.x

Bush AO, Lafferty KD, Lotz JM, Shostaak AW (1997) Parasitology meets ecology on this terms: Margolis et al. revisited. J Parasitol 83:575-583. doi:10.2307/3284227

Calderon ML, Santos RP, Vallejo AI (2003) Prevalencia de ectoparasitos en cachama hibrida (Colossoma macropomun $\times$ Piaractus brachypomus) y bocachico (Prochilodus magdaleane) en tres estaciones piscicolas del municipio de Monteria, Colombia. Rev MVZ 8:81-276

Carnevia D, Speranza G (2003a) Seasonal variations in parasites found in mullet (Mugil platanus Günther, 1880) juveniles captured on the Uruguayan coast of the River Plate. Bull Eur Ass Fish Pathol 5:245-249

Carnevia D, Speranza G (2003b) Enfermedades diagnosticadas en peces ornamentales tropicales de criaderos de Uruguay: I. Parasitosis. Vet Montev 38:29-34

Carnevia D, Perretta A, Letamendía M, Delgado E (2010) Enfermedades diagnosticadas en organismos acuáticos de cultivo en Uruguay. Agrociencia 14:109-113

Carraschi SP, Barbuio R, Ikefuti CV, Florêncio T, Cruz C, Ranzani-Paiva MJT (2014) Effectiveness of therapeutic agents in disease treatment in Piaractus mesopotamicus. Aquaculture 431:124-128. doi:10.1016/j.aquaculture.2013.12.026

Carrillo DFA, Aza FGG, Suárez AT, Nossa MO (2007) Estudio ictioparasitológico de las especies cachama (Piaractus brachypomus) y mojarra roja (Oreochromis spp.) en el Parque Ecológico "El Portal", municipio de Rionegro, Santander. Revista Spei Domus 6-7:8-13 
Cavichiolo F, Vargas L, Ribeiro RP et al (2002) Efeito da suplementação de vitamina $C$ e vitamina $E$ na dieta, sobre a ocorrência de ectoparasitos, desempenho e sobrevivência em larvas de tilápia do Nilo (Oreochromis niloticus L.) durante a reversão sexual. Acta Sci 24:943-948. doi:10. 4025/actascianimsci.v24i0.2444

Ceccarelli PS, Figueira LB, Ferraz de Lima CLB, Oliveira CA (1990) Observações sobre a ocorrência de parasitos no CEPTA entre 1983 e 1990. B Tec Cepta 3:43-55

Centeno L, Silva-Acuña A, Silva-Acuña R, Pérez J (2004) Fauna ectoparasitaria asociada a Colossoma macropomum y al híbrido de C. macropomum $\times$ Piaractus brachypomus, cultivados en el estado delta Amacuro, Venezuela. Bioagro 16:121-126

Chitmanat C, Tongdonmuan K, Nunsong W (2005) The use of crude extracts from traditional medicinal plants to eliminate Trichodina sp. in tilapia (Oreochromis niloticus) fingerlings. Songklanakarin J Sci Technol 27:359-364

Chu C, Zhang QZ, Luo F (2010) Effect of twenty Chinese herbal medicines on killing trophonts, cysts and theronts of Ichthyophthirius multifiliis in vitro. Freshw Fish 40:55-60

Colorni A, Diamant A (2005) Hyperparasitism of trichodinid ciliates on monogenean gill flukes of two marine fish. Dis Aquat Org 65:177-180

Compêndio de Produtos Veterinários [SINDAN] (2016). http:// www.cpvs.com.br/cpvs/pesquisar.aspx. Accessed 25 Aug 2016

Conroy G (2001) Diseases Found in Tilapia Culture in Latin America. The Advocate, December:52-55. http://pdf. gaalliance.org/pdf/GAA-Conroy-Dec01.pdf. Accessed 25 Aug 2016

Dar SA, Kaur H, Chishti MZ, Ahmad F, Tak Iu, Dar GH (2016) First record of protozoan parasites in cyprinid fish, Schizothorax niger Heckel, 1838 from Dal lake in Kashmir Himalayas with study on their pathogenesis. Microb Pathog 93:100-104. doi:10.1016/j.micpath.2016.01.015

Delgado JPM, Malta JC, Orbe RI, Chu-Koo FW, Gomes ALS, Martin ST (2007) Metazoarios parásitos de paiches adultos Arapaima gigas (Osteoglossiformes: Arapaimidae), cultivados en la Amazonía Peruana. Folia Amazonica 16:63-68

Delgado PM, Delgado JPM, Orbe RI (2013) Parasitic infections in juveniles of Arapaima gigas (Schinz, 1822) cultivated in the Peruvian Amazon. Ann Parasitol 59:43-48. doi:10. $1155 / 2014 / 245878$

Dias RJP, Fernandes NM, Sartini B, Silva-Neto ID, D'Agosto M (2009) Occurrence of Trichodina heterodentata (Ciliophora: Trichodinidae) infesting tadpoles of Rhinella pombali (Anura: Bufonidae) in the Neotropical area. Parasitol Int 58:471-474. doi:10.1016/j.parint.2009.06.009

Dias MKR, Neves LR, Marinho RGB, Pinheiro DA, TavaresDias M (2015) Parasitismo em tambatinga (Colossoma macropomum $\times$ Piaractus brachypomus, Characidae) cultivados na Amazônia, Brasil. Acta Amazonica 45:231-238. doi:10.1590/1809-4392201400974

Diggles BK (2000) Chemotherapy of the ciliate Trichodina sp. on juvenile turbot (Colistium nudipinnis) with notes on the susceptibility of fish with abnormal pigmentation. N Z J Mar Freshw 34:645-652. doi:10.1080/00288330.2000.9516965

Eiras JC, Takemoto RM, Pavanelli GC (2006) Métodos de estudo e técnicas laboratoriais em parasitologia de peixes. Universidade Estadual de Maringá, Maringá
Eisa ME, El-Shazly SO, Rizk MH (1985) A Contribution to the pathological changes of ectoparasite trichodinids-affected salt water fish (Grey Mullet fingerlings) in Raswa fish farm. J Egypt Vet Med 45:107-113

Fajer-Ávila EJ, Parra IA, Aguilar-Zarate G, Contreras-Arce R, Ramírez JZ, Betancourt-Lozano M (2003) Toxicity of formalin to bullseye puffer fish (Sphoeroides annulatus Jenyns, 1843) and its effectiveness to control ectoparasites. Aquaculture 223:41-50. doi:10.1016/S0044-8486(03)00 $166-2$

Fernandes NM, Sartini B, Dias RJP, D'Agosto M (2011) Quantitative study of Trichodina heterodentata (Ciliophora: Mobilia) infrapopulations infesting tadpoles of a Brazilian endemic toad Rhinella pombali (Anura: Bufonidae). Zoologia 28:777-783. doi:10.1590/S1984-467020 11000600011

Figueira LB, Ceccarelli OS (1991) Observações sobre a presença de ectoparasitas em pisciculturas tropicais de interior (CEPTA e região). B Tec Cepta 4:57-65

Franceschini L, Zago AC, Schalch SHC, Garcia F, Romera DM, Silva RJ (2013) Parasitic infections of Piaractus mesopotamicus and hybrid (P. mesopotamicus $\times$ Piaractus brachypomus) cultured in Brazil. Rev Bras Parasitol Vet 22:407-414. doi:10.1590/S1984-29612013000300015

Francis-Floyd R (1995) The use of salt in aquaculture. University of Florida. Cooperative Extension Service, pp 3. http:// fisheries.tamu.edu/files/2013/09/The-Use-of-Salt-inAquaculture.pdf. Accessed 25 Aug 2016

Fu Y, Zhang Q, Xu DH et al (2014) Parasiticidal effects of Morus alba root bark extracts against Ichthyophthirius multifiliis infecting grass carp. Dis Aquat Org 108:129136. doi: $10.3354 /$ dao02708

Garcia F, Fujimoto RY, Martins ML, Moraes FR (2009) Protozoan parasites of Xiphophorus spp. (Poeciliidae) and their relation with water characteristics. Arq Bras Med Vet Zootec 61:156-162. doi:10.1590/S0102-093520090001 00022

Garcia F, Romera DM, Gozi KS et al (2013) Stocking density of Nile tilapia in cages placed in a hydroelectric reservoir. Aquaculture 410-411:51-56. doi:10.1016/j.aquaculture. 2013.06.010

Gaze WH, Wootten R (1998) Ectoparasitic species of the genus Trichodina (Ciliophora: Peritrichida) parasitising British freshwater fish. Folia Parasit 45:177-190

Ghiraldelli L, Martins ML, Jerônimo GT, Yamashita MM, Adamante WB (2006) Ectoparasites communities from Oreochromis niloticus cultivated in the State of Santa Catarina, Brazil. J Fish Aquat Sci 1:181-190. doi:10.1590/ S1984-29612014041

Gong Y, Yu Y, Villalobo E, Zhu F, Miao W (2006) Reevaluation of the phylogenetic relationship between mobilid and sessilid peritrichs (Ciliophora, Oligohymenophorea) based on small subunit rRNA gene sequences. J Eukaryot Microbiol 53:397-403. doi:10.1111/j.1550-7408.2006.001 21. $\mathrm{x}$

Gonzales-Fernández JG (2012) Parasitofauna of tilapia cause mortalities in fingerlings in two fish farms, Lima, Peru. Neotrop Helminthol 6:219-229

Guerra H (2002) Producción y Manejo de Alevinos de Paiche. Instituto de Investigaciones de la Amazonía Peruana, Iquitos 
Harms CA (1996) Treatment for parasitic diseases of aquarium and ornamental fish. Semin Avian Exot Pet Med 5:54-63. doi:10.1016/S1055-937X(96)80018-1

Hossain MD, Hossain MK, Rahman MH, Akter K, Khanom DA (2008) Prevalence of ectoparasites of carp fingerlings at Santaher, Bogra. Univ J Zool Rajshahi Univ 27:17-19

Ikefuti CV, Carraschi SP, Barbuio R, Cruz C, Pádua SB, Onaka EM, Ranzani-Paiva MJT (2015) Teflubenzuron as a tool for control of trichodinids in freshwater fish: Acute toxicity and in vivo efficacy. Exp Parasitol 154:108-112. doi:10. 1016/j.exppara.2015.04.007

Insaurralde M, Romero R (2013) Parasitósis externa en las principales especies de peces del Lago Yparacaraí. Compend Cienc Vet 3:7-10

Instituto Brasileiro de Geografia e Estatística [IBGE] (2014) Produção da Pecuária Municipal 2014, vol 42. IBGE, Rio de Janeiro http://biblioteca.ibge.gov.br/visualizacao/periodicos/ 84/ppm_2014_v42_br.pdf. Accessed 25 Aug 2016

Jerônimo GT, Speck GM, Cechinel MM, Gonçalves ELT, Martins ML (2011) Seasonal variation on the ectoparasitic communities of Nile tilapia cultured in three regions in southern Brazil. Braz J Biol 71:365-373. doi:10.1590/ S1519-69842011000300005

Jerônimo GT, Marchiori NC, Pádua SB et al (2012) Trichodina colisae (Ciliophora: Trichodinidae): new parasite records for two freshwater fish species farmed in Brazil. Rev Bras Parasitol Vet 21:366-371

Kent ML, Fournie JW (2007) Parasites of fishes. In: Baker DG (ed) Flynn's parasites of laboratory animals. Blackwell Publishing, Ames, pp 69-110

Khan RA, Díaz F, George-Nascimento M (2008) Two new protist species, Trypanoplasma ojedae sp. n. (Mastigophora: Kinetoplastida) and Trichodina lascrucensis sp. $\mathrm{n}$. (Ciliophora: Peritrichida) in a blenniid fish, Scartichthys viridis, from the coast of Chile. Rev Biol Mar Oceanogr 43:585-590. doi:10.4067/S0718-19572008000300017

Khoshnood Z, Khoshnood R (2014) Histopathological Effects of Trichodiniasis in farmed freshwater rainbow trout, $\mathrm{On}$ corhynchus mykiss in West of Iran. Int Sch Sci Res Innov 8:1159-1162

Klein BM (1958) The "dry" silver method and its proper use. J Protozool 5:99-103. doi:10.1111/j.1550-7408.1958. tb02535.x

Kumar S, Raman RP, Kumar K et al (2012) In vitro and in vivo antiparasitic activity of Azadirachtin against Argulus spp. in Carassius auratus (Linn. 1758). Parasitol Res 110: 1795-1800. doi:10.1007/s00436-011-2701-0

Lay BA (1971) Applications for Potassium permanganate in fish culture. Trans Am Fish Soc 100:813-816. doi:10.1577/ 1548-8659(1971)100<813:AFPPIF>2.0.CO;2

Lom J, Dykova I (1992) Protozoan parasites of fishes. Developments in aquaculture and fisheries science, vol 26. Elsevier Science, Amsterdan

Madsen HCK, Buchmann K, Mellergaard S (2000) Treatment of trichodiniasis in eel Anguilla anguilla reared in recirculation systems in Denmark: alternatives to formaldehyde. Aquaculture 186:221-231. doi:10.1016/S0044-8486(99) 00379-8

Marchiori N, Martins ML (2012) Contribuições à taxonomia de Trichodina com revisão da distribuição do gênero. In: Silva-Souza AT, Lizama MAP, Takemoto RM (org.)
Patologia e Sanidade de Organismos Aquáticos. Massoni, Maringá, pp 105-124

Marcotegui OS, Martorelli SR (2009) Trichodinids (Ciliophora: Peritrichida) of Mugil platanus (Mugiliformes: Mugilidae) and Micropogonias furnieri (Perciformes: Sciaenidae) from Samborombón Bay, Argentina, with the description of a new species. Folia Parasit 56:167-172

Martins ML, Ghiraldelli L (2008) Trichodina magna Van As and Basson, 1989 (Ciliophora: Peritrichia) from cultured Nile tilapia in the state of Santa Catarina, Brazil. Braz J Biol 68:631-637. doi:10.1590/S1519-69842008000100 024

Martins ML, Moraes FR, Fujimoto RY et al (2000) Parasitic infections in cultuvated freshwater fishes. A survey of diagnosticated cases from 1993 to 1998 . Brazil. J. Vet. Parasitol. 9:23-28. http://cbpv.org.br/rbpv/documentos/ 912000/c9123_28.pdf

Martins ML, Onaka EM, Moraes FR, Bozzo FR, Paiva AMFC, Gonçalves A (2002) Recent studies on parasitic infections of freshwater cultivated fish in the state of São Paulo, Brazil. Acta Sci Anim Sci 24:981-985. doi:10.4025/ actascianimsci.v24i0.2460

Martins ML, Azevedo TOM, Ghiraldelli L, Bernardi N (2010a) Can the parasitic fauna on Nile tilapias be affected by different production systems? An Acad Bras Cienc 82: 493-500. doi:10.1590/S0001-37652010000200024

Martins ML, Marchiori N, Nunes G, Rodrigues MP (2010b) First record of Trichodina heterodentata (Ciliophora: Trichodinidae) from channel catfish, Ictalurus punctatus cultivated in Brazil. Braz J Biol 70:637-644. doi:10.1590/ S1519-69842010000300022

Martins ML, Shoemaker CA, Xu D, Klesius PH (2011) Effect of parasitism on vaccine efficacy against Streptococcus iniae in Nile tilapia. Aquaculture 314:18-23. doi:10.1016/j. aquaculture.2011.01.022

Martins ML, Marchiori N, Roumbedakis K, Lami F (2012) Trichodina nobilis hen, 1963 and Trichodina reticulata Hirschmann et Partsch, 1955 from ornamental freshwater fishes in Brazil. Braz J Biol 72:281-286. doi:10.1590/ S1519-69842012000200008

Martins ML, Cardoso L, Marchiori N, Pádua SB (2015) Protozoan infections in farmed fish from Brazil: diagnosis and pathogenesis. Braz J Vet Parasitol 24:1-20. doi:10.1590/ S1984-29612015013

Martins ML, Marchiori N, Bittencourt LS, Tavares-Dias M (2016) A new species of Tripartiella (Ciliophora: Trichodinidae) from Aequidens tetramerus (Perciformes: Cichlidae) in north Brazil. Braz J Biol 76:435-438. doi:10.1590/ 1519-6984.19014

Marzouk MSM, Mahdy OA, El-Khati NR, Yousef NSI (2013) A contribution in ectoparasitic infection and its control in cultured Oreochromis niloticus in Egypt. Am J Res Commun 1:326-338

Mehlhorn H, Schmahl G, Haberkorn A (1988) Toltrazuril effective against a broad spectrum of protozoan parasites. Parasitol Res 75:64-66

Miranda LH, Marchiori N, Alfaro CR, Martins ML (2012) First record of Trichodina heterodentata (Ciliophora: Trichodinidae) from Arapaima gigas cultivated in Peru. Acta Amazonica 42:433-438. doi:10.1590/S0044-59672012 000300016 
Mohammadi F, Mousavi SM, Annahita Rezaie A (2012) Histopathological study of parasitic infestation of skin and gill on Oscar (Astronotus ocellatus) and discus (Symphysodon discus). Int J Bioflux Soc 5:88-93

Mujica ME, Armas GC (1985) Una trematodosis en Colossoma macropomum (Cuvier, 1818) bajo condiciones de cultivo. Rev Fac Cienc Vet 32:103-111

Neguenga D (1988) A note on infestation of Oreochromis niloticus with Trichodina sp. and Dactylogyrus sp. In: Pullin RSV, Bhukaswan T, Tonguthai K, Maclean JL (eds) The second international symposium on tilapia in aquaculture. ICLARM conference proceedings, vol 15, pp 117-119

Neves LR, Pereira FB, Tavares-Dias M, Luque JL (2013) Seasonal influence on the parasite fauna of a wild population of Astronotus ocellatus (Perciformes: Cichlidae) from the Brazilian Amazon. J Parasitol 99:718-721. doi:10.1645/ 12-84.1

Noga EJ (2010) Fish disease: diagnosis and treatment. Iowa State University Press, Iowa

Noor El Deen AIE (2010) Green tea extract role in removing the Trichodina sp. on Oreochromis niloticus fry in the Egyptian fish hatcheries. Rep Opin 2:77-81

Noor El Deen AIE, Mohamed RA (2010) Application of some medicinal plants to eliminate Trichodina sp. in tilapia (Oreochromis niloticus). Rep Opin 2:54-59

Ogut H, Palm HW (2005) Seasonal dynamics of Trichodina spp. on whiting (Merlangius merlangus) in relation to organic pollution on the eastern Black Sea coast of Turkey. Parasitol Res 96:149-153. doi:10.1007/s00436-005-1346-2

Özer A, ÖztÜrk T, Kornyychuk YM, Yurakhno V (2015) Trichodina gobii (Ciliophora: Trichodinidae) on whiting Merlangius merlangus with a checklist from turkish and russian coasts of the black sea. Acta Zool Acad Sc H 61:119-134. doi:10.17109/AZH.61.2.119.2015

Pádua SB, Cruz C (2014) Health challenges in tilapia culture in Brazil. AQUA Cult Asia Pac Mag 10:37-39. http://www. springer.com/life+sciences/ecology/journal/11160?details Page=pltci_2862432. Accessed 25 Aug 2016

Pádua SB, Ishikawa MM, Kasai RYK, Jerônimo GT, CarrijoMauad JR (2012a) Parasitic infestations in hybrid surubim catfish fry (Pseudoplatystoma reticulatum $\times P$. corruscans). Rev Bras Med Vet 34:235-240

Pádua SB, Martins ML, Carraschi SP, Cruz C, Ishikawa MM (2012b) Trichodina heterodentata (Ciliophora: Trichodinidae): a new parasite for Piaractus mesopotamicus (Pisces: Characidae). Zootaxa 3422:62-68

Pádua SB, Menezes-Filho RN, Martins ML et al (2015) A survey of epitheliocystis disease in farmed Nile tilapia (Oreochromis niloticus Linnaeus, 1758) in Brazil. J Appl Ichthyol 31:927-930. doi:10.1111/jai.12840

Palm HW, Dobberstein RC (1999) Occurence of trichodinid ciliates (Peritricha: Urceolariidae) in the Kiel Fjord, Baltic Sea, and its possible use as a biological indicator. Parasitol Res 85:726-732. doi:10.1007/s004360050622

Pantoja WMF, Neves LR, Dias MRD, Marinho RGB, Montagner D, Tavares-Dias M (2012) Protozoan and metazoan parasites of Nile tilapia Oreochromis niloticus cultured in Brazil. Rev MVZ Córdoba 17:2812-2819

Piazza RS, Martins ML, Guiraldelli L, Yamashita MM (2006) Parasitic diseases of freshwater ornamental fishes commercialized in Florianópolis, Santa Catarina, Brazil. B Inst Pesca 32:51-57

Pinto HA, Wieloch AH, Melo AL (2006) Uma nova espécie de Trichodina Ehrenberg, 1838 (Ciliophora: Trichodinidae) em Biomphalaria schrammi (Crosse, 1864) (Mollusca: Planorbidae). Lundiana 7:121-124

Pinto E, Garcia AM, Figueiredo HCP, Rodrigues MP, Martins ML (2009) Primeiro relato de Tripartiella sp. (Ciliophora: Peritrichia) em Pseudoplatystoma corruscans (Osteichthyes: Pimelodidae) cultivado no Estado de Mato Grosso do Sul, Brasil, com descrição de nova espécie. B Inst Pesca 35:91-97

Pulido EA, Iregui C (2008) Manual basico de sanidad de pacús y tambaquís. Santa Cruz, Industrias Gráficas Sirena, p 53

Rach JJ, Gaikowski MP, Ramsay RT (2000) Efficacy of hydrogen peroxide to control parasitic infestations on hatchery-reared fish. J Aquat Anim Health 12:267-273. doi:10.1577/1548-8667(2000)012<0267:EOHPTC $>2.0$. $\mathrm{CO} ; 2$

Ranzani-Paiva MJT, Felizardo NN, Luque JL (2005) Parasitological and hematological analysis of Nile tilapia Oreochromis niloticus Linnaeus, 1757 from Guarapiranga Reservoir, São Paulo State, Brazil. Acta Sci Biol Sci 27:231-237

Rocha RCGA, Ceccarelli PS, Melo JSC, Souza Filho VM (1993) Eficiência de produtos químicos no combate a infestações do parasito Trichodina sp. em lambari Astyanax bimaculatus (Linnaeus, 1758). B Tec CEPTA 6:31-39

Rojas A, Wadsworth S (2007) A review of cage aquaculture: Latin America and the Caribbean. In: Halwart M, Soto D, Arthur JR (eds) Cage aquaculture -Regional reviews and global overview. FAO Fisheries Technical Paper, 498, Rome, FAO, pp 70-100

Sabry RC, Magalhães ARM (2005) Parasitas em ostras de cultivo (Crassostrea rhizophorae e Crassostrea gigas) da Ponta do Sambaqui, Florianópolis, SC. Arq Bras Med Vet Zootec 57:194-203. doi:10.1590/S0102-093520050008 00010

Sanabria YAP (2012) Historia de la Acuicultura en Colombia. Revista AquaTIC 37:60-77

Santos MA, Jerônimo GT, Cardoso L, Tancredo KR, Medeiros PB, Ferrarezi JV, Gonçalves ELT, Assis GC, Martins ML (2017) Parasitic fauna and histopathology of farmed freshwater ornamental fish in Brazil. Aquaculture 470:103-109

Schalch SHC, Moraes FR (2005) Distribuição sazonal de parasitos branquiais em diferentes espécies de peixes em pesque-pague do município de Guariba-SP, Brasil. Braz J Vet Parasitol 14:141-146

Serrano-Martínez E, Tantaleán MV, Leguía GP, Quispe MH, Casas GCV (2015) Parásitos en Arapaima gigas de la Amazonía Peruana según grupo etario. Rev Inv Vet Peru 26:303-309. doi:10.15381/rivep.v26i2.11014

Serviço Brasileiro de Apoio às Micro e Pequenas Empresas [SEBRAE] (2013) Manual de boas práticas de reprodução do pirarucu em cativeiro. SEBRAE, Brasília, DF

Silva-Briano M, Suárez-Morales E, Adabache Ortiz A, ReyesFlores M (2011) Two species of Mastigodiaptomus (Copepoda: Diaptomidae), hosts of the epibiotic ciliate Trichodina diaptomi (Peritricha) in North America. J Limnol 70:329-333. doi:10.4081/jlimnol.2011.329 
Singhal RN, Jeet S, Davies RW (1986) Chemotherapy of six ectoparasitic diseases of cultured fish. Aquaculture 54:165-171. doi:10.1016/0044-8486(86)90325-X

Sommerville C, Endris R, Bell TA, Ogawa K, Buchmann K, Sweeney D (2016) World association for the advancement of veterinary parasitology (WAAVP) guideline for testing the efficacy of ectoparasiticides for fish. Vet Parasitol 219:84-99. doi:10.1016/j.vetpar.2015.11.003

Tang FH, Zhao YJ, Warren A (2013) Phylogenetic analyses of trichodinids (Ciliophora, Oligohymenophora) inferred from 18S rRNA gene sequence data. Curr Microbiol 66:306-313. doi:10.1007/s00284-012-0274-5

Tang F, Zhang Y, Zhao Y (2017) Morphological and molecular identification of the new species, Trichodina pseudoheterodentata sp. n. (Ciliophora, Mobilida, Trichodinidae) from the channel catfish, Ictalurus punctatus, in Chongqing China. J Eukaryot Microbiol 64:45-55. doi:10.1111/jeu. 12335

Tanzola RD, Semenas L, Viozzi G (2009) Manejo y estado actual del conocimiento de los parásitos de peces cultivados en Argentina. In: Tavares-Dias M (org.) Manejo e Sanidade de Peixes em Cultivo. Embrapa Amapá, Macapá, pp 438-468

Tavares-Dias M, Martins ML, Moraes FR (2001) Fauna parasitária de peixes oriundos de "pesque-pague" do município de Franca, São Paulo, Brasil. I. Protozoários. Rev Bras Zool 18:67-79

Tavares-Dias M, Lemos JRG, Martins ML, Jerônimo GT (2009) Metazoan and protozoan parasites of freshwater ornamental fish from Brazil. In: Tavares-Dias M (org.). Manejo e Sanidade de Peixes em Cultivo. Embrapa Amapá, Macapá, pp 469-494

Tavares-Dias M, Lemos JRG, Martins ML (2010) Parasitic fauna of eight species of ornamental freshwater fish species from the middle Negro River in the Brazilian Amazon Region. Rev Bras Parasitol Vet 19:103-107. doi:10.4322/ rbpv.01902007

Tavares-Dias M, Marchiori NC, Martins ML (2013) Paratrichodina africana (Ciliophora: Trichodinidae) of wild and cultured Nile tilapia in the Northern Brazil. Rev Bras Parasitol Vet 22:248-252. doi:10.1590/S1984-2961201 3005000025

Tomec M, Hacmanjek M, Teskeredzic Z, Teskeredzic E, CozRakovac R (1995) Kvaliteta vode I ektoparazitarne bolesti ciprinidnih riba. Ribarstvo 53:129-139

Utz LRP, Eizirik E (2007) Molecular phylogenetics of subclass Peritrichia (Ciliophora: Oligohymenophorea) based on expanded analyses of 18S rRNA sequences. J Eukaryot Microbiol 54:303-305. doi:10.1111/j.1550-7408.2007.00 260.x

Valladão GMR, Pádua SB, Gallani SU et al (2013) Paratrichodina africana (Ciliophora): a pathogenic gill parasite in farmed Nile tilapia. Vet Parasitol 197:705-710. doi:10. 1016/j.vetpar.2013.04.043

Valladão GMR, Gallani SU, Pádua SB, Martins ML, Pilarski F (2014) Trichodina heterodentata (Ciliophora) infestation on Prochilodus lineatus larvae: a host-parasite relationship study. Parasitology 141:662-669. doi:10.1017/S0031182 013001480

Valladão GMR, Giannecchini LG, Martins ML, Pádua SB (2015) Trichodina modesta: an exotic ciliate in the
Neotropical region parasitizing an unusual host. Braz J Vet Parasitol 24:162-167. doi:10.1590/S1984-29612015024

Valladão GMR, Alves LO, Pilarski F (2016a) Trichodiniasis in Nile tilapia hatcheries: diagnosis, parasite: host-stage relationship and treatment. Aquaculture 451:444-450. doi:10.1016/j.aquaculture.2015.09.030

Valladão GMR, Gallani SU, Pilarski F (2016b) South American fish for continental aquaculture. Rev Aquac 0:1-19. doi:10. 1111/raq.12164

Van As JG, Basson L (1987) Host specificity of trichodinid ectoparasites of freshwater fish. Parasitol Today 3:88-90. doi:10.1016/0169-4758(87)90166-9

Van As JG, Basson L (1989) A further contribution to the taxonomy of the Trichodinidae (Ciliophora: Peritrichia) and a review of the taxonomic status of some fish ectoparasitic trichodinids. Syst Parasitol 14:157-179. doi:10.1007/ BF02187051

Vanotti MD, Tanzola RD (2005) Relación entre la carga parasitaria total y algunos parâmetros hematológicos de Rhamdia sapo val. (Pisces) en condiciones naturales. Biología Acuática 22:247-256

Vargas L, Povh JA, Ribeiro RP, Moreira HLM (2000) Ocorrência de ectoparasitos em tilápias do Nilo (Oreochromis niloticus), de origem tailandesa, em Maringá - Paraná. Arq Cien Vet Zool Unipar 3:31-37

Vargas L, Povh JA, Ribeiro RP, Moreira HLM, Loures BTRR, Maroneze MS (2003) Efeito do tratamento com cloreto de sódio e formalina na ocorrência de ectoparasitas em alevinos de Tilápia do Nilo (Oreochromis niloticus) revertidos sexualmente. Arquivos de Ciências Veterinárias e Zoologia da UNIPAR 6:39-47

Vázquez ND, Delgado PM, Chu-Koo FW, Martín ST, Orbe RI (2007) Fauna parasitaria de juveniles de Arahuana, Osteoglossum bicirrhosum (Vandelli, 1829) cultivados em el Centro de Investigaciones de Quistococha, Loreto, Peru. Folia Amazonica 16:29-33

Ventura S, Jerônimo GT, Gonçalves ELT, Tamporoski BRF, Martins ML, Ishikawa MM (2013) Fauna parasitária dos híbridos siluriformes cachapinta e jundiara nos primeiros estágios de desenvolvimento. Pesqui Agropec Bras 48:943-949. doi:10.1590/S0100-204X2013000800019

Verján N, Iregui CA, Rey AL, Donado P (2001) Sistematización y caracterización de las lesiones branquiales de la cachama blanca (Piaractus brachypomus) de cultivo clínicamente sana: algunas interacciones hospedador-patógeno-ambiente. Revista AquaTIC 15:1-21

Willomitzer J (1980) Therapy of major ectoparasitoses in grasscarp (Ctenopharyngodon idella) fry and fingerlings. Acta Vet Brno 49:279-282. doi:10.2754/avb198049030279

Wood J (1970) Introducción del Salmón del Pacífico en Chile. Informe sobre investigaciones en Piscicultura, Chile

Wu ZF, Zhu B, Wang Y, Lu C, Wang GX (2011) In vivo evaluation of anthelmintic potential of medicinal plant extracts against Dactylogyrus intermedius (Monogenea) in goldfish (Carassius auratus). Parasitol Res 108: 1557-1563. doi:10.1007/s00436-010-2211-5

Xu DH, Pridgeon JW, Klesius PH, Shoemaker CA (2012) Parasitism by protozoan Ichthyophthirius multifiliis enhanced invasion of Aeromonas hydrophila in tissues of channel catfish. Vet Parasitol 184:101-107. doi:10.1016/j.vetpar. 2011.09.020 
Yao J, Li X, Shen J et al (2011) Isolation of bioactive components from Chelidonium majus $L$. with activity against Trichodina sp. Aquaculture 318:235-238. doi:10.1016/j. aquaculture.2011.04.035

Yemmen C, Ktari ME, Bahri S (2011) Seasonality and histopathology of Trichodina puytoraci Lom, 1962, a parasite of flathead mullet (Mugil cephalus) from Tunisia. Acta Adriat 52:15-20

Yi YL, Lu C, Hu XG, Ling F, Wang GX (2012) Antiprotozoal activity of medicinal plants against Ichthyophthirius multifiliis in goldfish (Carassius auratus). Parasitol Res 111:1771-1778. doi:10.1007/s00436-012-3022-7

Zago AC, Franceschini L, Garcia F, Schalch SHC, Gozi KS, Silva RJ (2014) Ectoparasites of Nile tilapia (Oreochromis niloticus) in cage farming in a hydroelectric reservoir in Brazil. Rev Bras Parasitol Vet 23:171-178. doi:10.1590/ S1984-29612014041
Zhan Z, Xu K, Warren A, Gong Y (2009) Reconsideration of phylogenetic relationships of the subclass Peritrichia (Ciliophora, Oligohymenophorea) based on small subunit ribosomal RNA gene sequences, with the establishment of a new subclass Mobilia Kahl, 1933. J Eukaryot Microbiol 56:552-558. doi:10.1111/j.1550-7408.2009.00435.x

Zhan Z, Xu K, Dunthorn M (2013) Evaluating molecular support for and against the monophyly of the Peritrichia and phylogenetic relationships within the Mobilida (Ciliophora, Oligohymenophorea). Zool Scr 42:213-226. doi:10. 1111/j.1463-6409.2012.00568.x

Zhang Q, Xu D, Klesius PH (2013) Evaluation of an antiparasitic compound extracted from Galla chinensis against fish parasite Ichthyophthirius multifiliis. Vet Parasitol 198: 45-53. doi:10.1016/j.vetpar.2013.08.019 